\title{
Az IoT-koncepción alapuló egészségügyi eszközök fogyasztók közötti elterjedését befolyásoló faktorok vizsgálata
}

Napjainkban számos területen érezhetjük a digitalizáció pozitív hatását. Nincs ez máshogy az egészségügy területén sem, ahol az IoT-koncepció (Internet of Things) adatgyújtéssel, illetve a Big Data koncepció adatkezeléssel kapcsolatos megoldásai hozzájárulnak az adatorientált, személyre szabott egészségügyi döntésekhez. Jelen kutatás célja a fogyasztók témakörrel kapcsolatos véleményének felmérése, illetve a technológiai megoldások diffúzióját befolyásoló faktorok meghatározása annak érdekében, hogy a kutatás folytatásaként az igényekhez illeszkedő hardver- és szoftverplatform kialakítására nyíljon lehetőség. Az elfogadottságot befolyásoló tényezők vizsgálata érdekében kérdőíves felmérés történt öt fő témakört érintően, beleértve a különböző eszközökről és szolgáltatásokról alkotott véleményt. Az általános változók mellett a UTAUT2-technológia elfogadásának és használatának kiegészített modellje került alkalmazásra, a területhez való alkalmazkodás érdekében. Az elemzés során strukturális egyenletek modellezése (PLS-SEM) zajlott, majd az egyes tényezők látens változókra gyakorolt hatása ordinális logisztikus regresszióval került górcső alá, ezzel vizsgálva a modell fejlesztésének lehetőségeit.

Kulcsszavak: IoT, Big Data, egészségügy, technológiai elfogadottság, UTAUT2

\section{Köszönetnyilvánítás}

A publikáció elkészítését az EFOP-3.6.1-16-2016-00022 számú, Debrecen Venture Catapult Program című projekt támogatta. A projekt az Európai Unió támogatásával, az Európai Szociális Alap társfinanszírozásával valósult meg

\section{Szerzői információ}

Tóth Mihály, Debreceni Egyetem Gazdaságtudományi Kar, Ihrig Károly Gazdálkodás- és Szervezéstudományok Doktori Iskola, https://orcid.org/0000-0002-8367-4945

Szilágyi Róbert, Debreceni Egyetem Gazdaságtudományi Kar https://orcid.org/0000-0002-1783-6483

Így hivatkozzon erre a cikkre:

Tóth Mihály, Szilágyi Róbert. „Az IoT-koncepción alapuló egészségügyi eszközök fogyasztók közötti elterjedését befolyásoló faktorok vizsgálata”. 


\section{Investigation of the factors influencing the diffusion of health devices among consumers based on the IoT concept}

Nowadays, several fields are able to benefit from digitalization. Healthcare is no exception, where data acquisition, based on the IoT (Internet of Things) and data management, based and Big Data concept contributes to data-driven, personalized healthcare decisions. The aim of this research is to determine consumer opinions and factors, influencing the diffusion of technological innovations, to facilitate the development of a customized hardware and software platform. A questionnaire was conducted to examine the determinants of acceptance, covering five main topics, including views on different systems and services. In addition to the generic variables, the UTAUT2 technology acceptance model was implemented and extended to in order to adopt the characteristics of the field. Structural equation modelling (PLS-SEM) was applied in the analysis, followed by the assessment of the effects of certain factors on the latent variables by ordinal logistic regression, thus exploring the possibilities of further developing the model.

Keywords: IoT, Big Data, healthcare, technology acceptance, UTAUT2 


\section{Bevezetés}

Egyre nagyobb számban találkozhatunk krónikus betegségben szenvedő betegekkel, melynek kialakulásához nagyban hozzájárulnak a helytelen étkezési szokások, a fizikai aktivitás hiánya és a magas alkoholfogyasztás (Gómez, Oviedo és Zhuma 2016). Ezenfelül a nem fertőző (szív- és érrendszeri, cukor-, daganatos és krónikus légúti) betegségek jelentős mértékben követelnek áldozatokat (Puri et al. 2020). Az aktivitás és az étkezési szokások kulcsfontosságú faktorként befolyásolják az említett egészségügyi problémák előfordulását (Sikorska-Siudek, Olędzka-Orȩziak és Parzuchowska 2006; WHO 2003). Ezek leküzdése és megelőzése döntéseket igényel a fizikai aktivitás, étkezés, gyógyszeradatok meghatározása tekintetében, melyekhez egyes paraméterek (például: vérnyomás, súly) méréseire van szükség, ám ezek egyfelől sok esetben nem kerülnek megvalósításra (McConnell et al. 2018), másfelől viszont a megfelelő mérések esetében sem garantált az adatok releváns alkalmazása. A napjainkban egyre gyakrabban felmerülő Smart Health (okos egészségügy) koncepció felvázolja a felhasználók életkörülményeinek és egészségügyi állapotának folyamatos felügyeletét érzékelésre alkalmas eszközök segítségével. A rögzített adatok ezt követően a hálózaton keresztül továbbításra kerülnek, elősegítve ezzel - különböző társított módszerekkel együtt - a preventív egészségügyet (Suzuki et al. 2013). A jövőben hatékonyabb egészségügyi szolgáltatások lesznek alkalmazhatók az adatok elérhetősége révén, beleértve a csökkenő bizonytalanságot, a betegek jobb tapasztalatait, valamint a távoli kezelését és a gyógyszermenedzsmentet (Puri et al. 2020). Az eszközök számos kategóriába sorolhatók, függően az alkalmazási területtől és kialakításuktól, ám abban azonosak, hogy segítségükkel csökkenthetők az ellenőrzési szükségletek, az orvosi ellátás igényének gyakorisága (Li et al. 2019), emellett hatékonyabb döntésekkel szembesülhetünk lokálisan és intézményi szinten egyaránt. A statisztikák alapján az EU-ban 2016-ban 870 ezer olyan eszköz állt a felhasználók birtokában, melyek megfelelnek az imént említett koncepciónak, ám ez a szám az előrejelzések alapján 2025-re 10,35 millióra nőhet, így mindenképp egy dinamikusan fejlődő és terjedésen lévő területről beszélünk (Statista 2020).

A továbbiakban az említett eszközök és a hozzájuk kapcsolódó szolgáltatások lehetőségeivel foglalkozunk, elsősorban fogyasztói oldalról, meghatározva a faktorokat, melyek befolyásolják a döntésüket, ezzel olyan tényezőkre világítva rá, melyek kritikusak lehetnek az egyes koncepciók kialakítása és rendszerek fejlesztése során a folyamat támogatása érdekében.

\section{Szakirodalmi áttekintés}

Az egészségügyben kialakuló digitalizáció nemcsak intézeti, hanem egyéni változtatásokat is igényel, mivel a lehetőségek által az egyént leíró adathalmaz nemcsak orvosi leletekből tevődik össze, de bármilyen, az egyén egészségét befolyásoló faktorok összességéből is, beleértve sporttevékenységet, utazási szokásokat, környezeti tényezőket, vitális paramétereket (Rajanen és Weng 2017), étkezési szokásokat (Resende Silva és Cui 2017) vagy bármilyen végzett tevékenységet (Su, Tong és Ji 2014). 
A digitalizációval együtt megjelent a Health 4.0 koncepció, mely jelentősen épít az Industry 4.0 koncepció meglévő pillérjeire, mint az IoT- (Internet of Things), vagy Big Data koncepció, emellett hasonló elvekkel jellemezhető, mint az interoperabilitás, virtualizáció, decentralizáció, valós idejű képesség, szolgáltatásorientáltság és modularitás (Thuemmler 2017). Mivel a bemutatásra kerülő kérdőívben két gyakorlati aspektusként az adatgyüjtés (eszközök) és az adatelemzés (módszerek) egyes lehetőségei kerülnek áttekintésre, a továbbiakban érdemes áttekinteni az ezekkel kapcsolatos alapvető információkat és módszereket a területen való alkalmazás lehetőségeinek bemutatásával.

Az első aspektushoz kapcsolódó IoT-koncepció (Internet of Things) egy folyamatosan bővülő technológiát takar. Az IoT az RFID (Radio Frequency Identification) egyedi azonosító és a WSN (Wireless Sensor Network) technológiai megoldás kapcsolatából kiindulva vált mára különálló koncepcióvá a felhőalapú számítási lehetőségekkel, internetszolgáltatásokkal, kiberfizikai rendszerekkel való komplexebb rendszerintegráció révén (Ullah et al. 2017). Az egészségügyben jellemző IoT-koncepció három kiterjedési szintet ölel föl, beleértve az adott személy hálózatot (hordható eszközök), az élőhely hálózatot (okosotthon), illetve a nagyobb kiterjedésű, integrált hálózatot (okosváros), egyre nagyobb halmazt képviselve (Farahani et al. 2018). Az IoT-koncepció hatékonysága a lehetőségek tekintetében új utat nyitott meg a területen az intelligens, költséghatékony, illetve pontos, személyre szabott szolgáltatások biztosítása révén (Khalil et al. 2014). Az IoT egészségügyben történő fokozott alkalmazása révén a szakirodalomban elterjedt az IoMT (Internet of Medical Things) kifejezés, mely kifejezetten biológiai szenzorokra és mesterséges intelligencián alapuló algoritmusokra értendő, mely külső szolgáltatásként közvetlenül kapcsolódik a szakértői rendszerekhez (Padikkapparambil et al. 2020). A koncepciót megvalósító WBAN (Wireless Body Area Network) rendszerek testhez vagy ruházathoz rögzített szenzorok segítségével képesek fizikai vagy egészségügyi paraméterek mérésére (Xing és Zhu 2009). A kutatás során külön kezeltük a hordható, az önálló, illetve a környezeti adatgyüjtő eszközöket. Az alkalmazott szenzorok tekintetében alkalmazási területtől függően invazív és nem invazív eszközöket különböztetünk meg (Ni et al. 2018). Hordható eszközök esetében megkülönbözettünk továbbá szenzorokat, illetve az általuk mért jellemzőket. A szenzoroknál jellemzően a hőmérsékletmérőket, a pulzoximétereket, az elektromyográfokat (EMG), elektroenkefalográfokat (EEG) említhetjük meg, melyek közül az utóbbi kettő döntően egyszerübb elektróda, ezenfelül vércukorszintmérőket, kémhatásmérőket (Indrakumari et al. 2020), piezoelektronikus vagy piezorezisztív szenzorokat (Chan et al. 2012), illetve leggyakrabb előforduló eszközként a gyorsulásmérőt, a giroszkópot, valamint a magnetométert. Környezeti adatgyüjtő eszközöknél a terület aspektusába illeszthető az okosotthon koncepciója révén a páratartalom-mérő, a szélsebességmérő, a CO2 koncentrációmérő (Sung és Hsiao 2020), a fényerősségmérő vagy akár a képérzékelő szenzor (Alemdar és Ersoy 2010). Az egyik egyszerübb esetet jelentő „point-of-care” elv alapján egyes rendszerek képesek mérést végrehajtani, majd az eredmények alapján jelentést adni a felhasználó számára (Merilampi és Sirkka 2016). Az ezt követő lépés a helyileg összekötött rendszerek hálózata (az említett okosotthon koncepciója által), mely esetben pontosabb következtetések levonására 
van lehetőség az adatok lokális, centralizált feldolgozása révén (Pham et al. 2018). A hálózati kiterjedés legfelső szintjét viszont a felhőalapú megoldások jelentik, amelyek megvalósítása érdekében jelentős feladat a jelenleg szerteágazó sztenderdek (kommunikációs protokollok, adattárolási modellek) kialakítása (Demski, Garde és Hildebrand 2016). A kutatást nehezíti ugyanis az orvosi adatok átfogó egységessége, a többlépcsős hozzáférés (jogosultságok), az eseményalapú betegirányítás, és a nyomonkövetési rendszerek. Valamint az API-alapú (alkalmazásprogramozási interfész) hozzáférési lehetőségek, melyek gyakorlatilag elérhetetlenek a számunkra (Paulin 2017), mégpedig ez kiemelt fontosságú az M2M (gép és gép közötti kommunikáció) kialakítása és a szoftverek közötti kommunikáció standardizálása érdekében. Az említett kommunikációs protokollok különböző szinten vannak jelen (Farahani et al. 2018), beleértve fizikai kapcsolatot (Bluetooth, WiFi, LoRa, ZigBee stb.), illetve adatszerkezeti szinten (MQTT, XMPP), ám jelen kontextusban sokkal fontosabb az adatok strukturálása annak érdekében, hogy ezek egységesen alkalmazhatóvá váljanak a személyi és intézményi döntéshozatalban.

A második aspektushoz kapcsolódó, egységesítést és adatmenedzsmentet támogató Big Data koncepció központi szerepet tölt be a modern egészségügy területén (YIN et al. 2016), elsődlegesen a területre jellemző adattípusok diverzitása, illetve a feldolgozás sebességének igénye révén. Big Data alatt olyan adathalmazokról beszélünk, melyek túl nagyok vagy szerkezetileg komplexek ahhoz, hogy relációs adatbázisban kerüljenek tárolásra (Panesar 2019). A Big Data olyan karakterisztikákat foglal magába, mint a terjedelem, a változatosság, a sebesség és az egészségügy területén különösen fontos tényezőként a valódiság - a megbízhatóság érdekében (Din és Paul 2019). Az egészségügyben betöltött szerepük révén a megoldások képesek a betegek viselkedését leíró adatok (közösségi média, okostelefonok, fórumok), a betegek egészségügyi paramétereit reprezentáló adatok (szenzorok, okostelefonok), gyógyszerészeti és kutatási adatok, általános egészségügyi statisztikák, klinikai adatok (EHR), panaszok, illetve tranzakciós adatok teljes integrálására, melyek ezt követően adatbányászaton keresztül, leíró, prediktív és előíró statisztikák segítségével támogatják a döntéseket az egyénre szabott gyógyászat, valós idejű felügyelet érdekében (Panesar 2019). Az aktuális koncepciók az úgynevezett ködalapú számítási lehetőségek köré épülnek. A koncepció lényege, hogy az adott eszköz által mért adatok, megbízható csatornákon keresztül, átjárók által jutnak el egy szerverre, ahol megtörténik azok értelmezése esetlegesen gépi tanulás alkalmazásával (Uddin et al. 2020). A szerveroldali feldolgozás előnye, hogy az ott rendelkezésre álló adatok volumene révén (tanulóadatok) pontosabb döntések születhetnek.

Az adatok felhasználását illetően a mesterséges intelligencia, azon belül is a gépi tanuló algoritmusok kiemelt szerepet játszanak a diagnózisok javítása, kimenetelek előrejelzése, illetve a személyre szabott gyógyászat területén (Panesar 2019). Az eszközök alkalmazása történhet helyben (az felhasználó készülékén), illetve szerveroldalon, a szolgáltatónál. Helyi megoldások kapcsán a legismertebb lehetőségként a tevékenységosztályozást érdemes megemlíteni, mely által egyszerübb tevékenységek, mint a sétálás, a futás, az ülés (Yin et al. 2015), a fekvés, a lépcsőzés osztályozhatók (Hung et al. 2014). Egyes megoldások segítségével lehetőség nyílik az érzelmi állapot osztályozására (szenzoros és gépelésből származó szöveges adatok figyelem- 
bevételével, Naïve Bayes, SVM (Support Vector Machine), J48 osztályozó algoritmusok segítségével (Zualkernan et al. 2017). Egyes kutatások fizikai aktivitás mintázatai és dietetikai adatok, SVM osztályozó algoritmus segítségével osztályozták az elhízás egyes formáit táplálkozási tanácsok nyújtása érdekében (Selya és Anshutz 2018). Étkezés tekintetében nem csak dietetikus tanácsadásról beszélünk, mivel egyes eszközök képesek a hőmérsékleten túl egyes mikrobiológiai információk és az élelmiszerek minőségét reprezentáló paraméterek mérésére is (Bosona és Gebresenbet 2013). Részben szolgáltatások kapcsán szintén számos lehetőség áll rendelkezésre, beleértve az idősek felügyeletét az okosotthon egyes komponenseinek segítségével (Kwon, Shim és Lim 2012).

Mint az sok esetben jellemző a technológiai innovációra, jelen esetben is fontos szempont az felhasználók általi elfogadottság kérdése, hiszen a faktorok ismerete a tervezési folyamaton felül támogatja az értékelést és az implementálást (Kijsanayotin, Pannarunothai és Speedie 2009). Számos elméleti modell áll rendelkezésre a pszichológia és a szociológia területén a technológia elfogadásának és használatának magyarázatára. Jelen kutatás hasonlóképpen az alkalmazási hajlandóságot befolyásoló faktorokkal, illetve a felhasználói véleményekkel, igényekkel foglalkozik, a kutatás folytatásaként egy felhasználóorientált hardver és szoftverplatform létrehozásának támogatásához. A kutatásokat áttekintve a többség strukturális egyenletek modellezése által igyekszik feltárni a befolyásoló tényezőket (Holden és Karsh 2010) egyéni vagy meglévő teoretikus modellek területspecifikus módosításával. A fő modellek közé sorolható a TAM (technológia elfogadottság modellje), a UTAUT (technológiaelfogadás és használat egységesített elmélete), a TPB (tervezett viselkedés elmélete), az IDT (innováció diffúzió elmélete) és egyebek (Kumar 2017). A szakirodalom ezen aspektusban elkülönül a különböző, döntően hordható eszközök, illetve a szoftverek (eszközökön futó és szerveroldali szolgáltatás) vizsgálatát illetően, ám egyes kutatások (Hsiao és Chen 2018) együtt igyekeznek megállapítani a komponensek felé irányuló nyitottságot. Az alábbiakban (1. táblázat) láthatunk több kutatást és az általuk alkalmazott modelleket.

\begin{tabular}{|c|c|c|c|}
\hline Vizsgálat tényező & Alkalmazott modell & $\begin{array}{l}\text { Közvetlenül ható, szignifi- } \\
\text { káns változók }\end{array}$ & Forrás \\
\hline $\begin{array}{l}\text { Okosórák használati } \\
\text { hajlandósága }\end{array}$ & Egyéni modell & $\begin{array}{l}\text { Észlelt hasznosság; Észlelt } \\
\text { élvezet }\end{array}$ & (Choi és Kim 2016) \\
\hline $\begin{array}{l}\text { Elektronikus egészség- } \\
\text { ügyi portál }\end{array}$ & UTAUT2, DOI és HBM & $\begin{array}{l}\text { Várható teljesítmény; } \\
\text { Szokás }\end{array}$ & (Tavares és Oliveira 2018) \\
\hline $\begin{array}{l}\text { Okosotthon koncepció } \\
\text { elfogadottsága }\end{array}$ & UTAUT2, kiegészítéssel & $\begin{array}{l}\text { Várható teljesítmény; } \\
\text { Szokás }\end{array}$ & (Akter et al. 2012) \\
\hline $\begin{array}{l}\text { Hordható eszközök elfo- } \\
\text { gadottsága }\end{array}$ & Egyéni modell & $\begin{array}{l}\text { Referenciacsoport hatása; } \\
\text { Érzékelt hasznosság; } \\
\text { Fogyasztói innováció }\end{array}$ & (Cheung et al. 2019) \\
\hline $\begin{array}{l}\text { Hordható eszközökben } \\
\text { való bizalom }\end{array}$ & UTAUT2, módosítással & $\begin{array}{l}\text { Várható teljesítmény; } \\
\text { Bizalom }\end{array}$ & (Gu, Wei és Xu 2015) \\
\hline $\begin{array}{l}\text { Hordható eszközök elfo- } \\
\text { gadottsága }\end{array}$ & UTAUT2, kiegészitéssel & $\begin{array}{l}\text { Várható teljesítmény; } \\
\text { Hedonikus motiváció; } \\
\text { Szociális hatás; Ár-érték }\end{array}$ & (Cho és Park 2016) \\
\hline
\end{tabular}




\begin{tabular}{|c|c|c|c|}
\hline $\begin{array}{l}\text { Okosórák használati } \\
\text { hajlandósága }\end{array}$ & TAM, kiegészítéssel & $\begin{array}{l}\text { Érzékelt hasznosság; } \\
\text { Érzékelt használati köny- } \\
\text { nyedség }\end{array}$ & $\begin{array}{l}\text { (Dutot, Bhatiasevi és } \\
\text { Bellallahom 2019) }\end{array}$ \\
\hline $\begin{array}{l}\text { Hordható eszközök elfo- } \\
\text { gadottsága }\end{array}$ & TAM, kiegészítéssel & $\begin{array}{l}\text { Érzékelt hasznosság; } \\
\text { Kompatibilitás; Szubjektív } \\
\text { egészségi állapot }\end{array}$ & (Li et al. 2019) \\
\hline
\end{tabular}

1. táblázat: Egyes kutatások során alkalmazott teoretikus modellek

Az aktuális kutatások döntő része a UTAUT2-modellt és módosítását preferálják, mint ahogy az jelen kutatás esetében is jellemző - melynek célja az elfogadottság, továbbá a technológiai adaptáció felmérése. A UTAUT-modell nyolc elmélet egyes elemeinek figyelembevételével került kialakításra, beleértve a TRA (Theory of Reasoned Action), TPB (Theory of Planed Behavior), TAM (Technology Acceptance Model), MM (Motivational Model), kombinált TAM-TPB, MPCU (Model of Personal Computer Utilization), IDT (Innovation Diffusion Theory) és SCT (Social Cognitive Theory) modelleket (Zahra et al. 2019). A hasonló modellek a szándékon alapulnak és a viselkedést befolyásoló elméleti mechanizmusok alapján kerülnek kialakításra (Venkatesh, Thong és Xu 2012). Az eredeti UTAUT-modell konstruktorai közé tartozik a várható teljesítmény, a várható erőfeszítés, a közösségi hatás, a támogató tényezők, illetve a viselkedési szándék. A várható teljesítmény célja a teljesítmény lehetséges növekedésének meghatározása. Mért változóinak forrása közé sorolandó több konstruktor, mint az észlelt hatékonyság (forrás: TAM), a külső motiváció (forrás: MM), a munka illeszkedése (forrás: MPCU), a relatív előny (forrás: IDT) és a kimeneti elvárások (forrás: SCT). A várható erőfeszítés célja az adott rendszer alkalmazására jellemző komplexitás. Mért változóinak forrása közé sorolandó az észlelt könnyü használat (forrás: TAM), a komplexitás (forrás: MPCU) és a könnyű használat (forrás: IDT). A közösségi hatás célja az egyes személyek befolyásoló hatásának meghatározása. Mért változóinak forrása közé sorolandó a szubjektív norma (forrás: TRA, TAM és TPB), a közösségi faktorok (forrás: MPCU) és az imázs (forrás: IDT). A támogató tényezők célja a használat során felmerülő segítség elérésének lehetőségét érinti. Mért változóinak forrása közé sorolandó az észlelt viselkedési kontroll (forrás: TPB és TAM), a támogató tényezők (forrás: MPCU) és a kompatibilitás (forrás: IDT) (Venkatesh et al. 2003). A UTAUT-modell elsődlegesen vállalati aspektusra koncentrált, ám a jelen esetben is implementált második változat nagyobb figyelmet fordít a fogyasztói szempontokra (Venkatesh, Thong és Xu 2012) a hedonikus motiváció, az ár-érték és a szokások konstruktorainak hozzáadásával (Rondan-Cataluña, Arenas-Gaitán és Ramírez-Correa 2015).

\section{A szakirodalom kvantitatív áttekintése}

A területre jellemző szakirodalom megfelelő áttekintés érdekében szokássá vált az egyes kutatások során a jellemzően kvalitatív módszerek mellett a kvantitatív megközelítés alkalmazása bibliográfiai elemzés formájában, melynek megvalósításához az adott területre jellemző kulcsszó-kombináció alapján a Web of Science adatbázisból származó adathalmaz került felhasználásra. Jelen esetben az alábbi kulcsz- 
szavak, illetve a közöttük definiált logikai kapcsolat alapján lekérdezett adathalmaz került felhasználásra: ((,wearables” OR „IoT” OR „Internet of Things” OR „Sensor networks”) AND („Health*” OR „Sport”)).

Mint azt látjuk, a fókusz az IoT-koncepción, a témakörhöz kötődően releváns hordható eszközökön, illetve ezek egészséggel és sporttal való kapcsolatán található, hogy ezek képviseljék az adathalmaz központi elemeit. E kulcsszó-kombináció a lekérdezés időszakában 10889 darab folyóiratcikket és más szakirodalmi művet reprezentáló adathalmazt (71 változó által kifejezve) eredményezett, mely a Web of Knowledge által indexelt bejegyzéseket tartalmazza. Az elemzések elvégzése érdekében e bejegyzések metaadataira volt szükség, kiemelt figyelmet fordítva a címre, a kulcsszavakra (szerzői és rendszer által hozzárendelt), az absztraktra, illetve a megjelenés időpontjára. A pontos megfogalmazás ellenére gyakran találkozni az adathalmazra jellemző zajra, mely tudományterületre vonatkozóan nem releváns bejegyzésekből ered. Az elemzések előtt e bejegyzések szűrésére volt szükség, mely egy szekvenciális folyamat, magában foglalva a szinonimak kezelését, emellett az irreleváns kulcsszavak vagy akár teljes rekordok eltávolítását. Mindkét művelet elvégzése előre definiált szótárak segítségével, erre a célra létrehozott célalkalmazás segítségével valósult meg. A szótárak mellett figyelem fordult az összefüggésekre is a megfelelő eredmény érdekében. Az adattisztítást követően az adatkeretben található rekordok száma 9 278-ra csökkent, ám a magyarázóereje lényegesen nőtt.

Az elemzések elvégzése érdekében egy meglévő programcsomag (Aria és Cuccurullo 2017) jelentősen módosított változata került alkalmazásra. Az első elemzés a területre jellemző témakörök, illetve a közöttük lévő kapcsolatok meghatározását teszi lehetővé közös elfordulásuk alapján, az előbb említett kulcsszavakat tartalmazó két változó, illetve az absztraktokból szövegbányászat segítségével meghatározott harmadik, szintén kulcsszavakat tartalmazó változók összevonásával. Az elemzés során a leginkább frekventált 150 kulcsszó alkalmazása történt meg. A hálózati elemzés során született egy közös előfordulást kifejező mátrix, mely minden kulcsszó-kombinációt magában foglal. A vizualizálás irányított gráfok segítségével történt (Kamada és Kawai 1989).

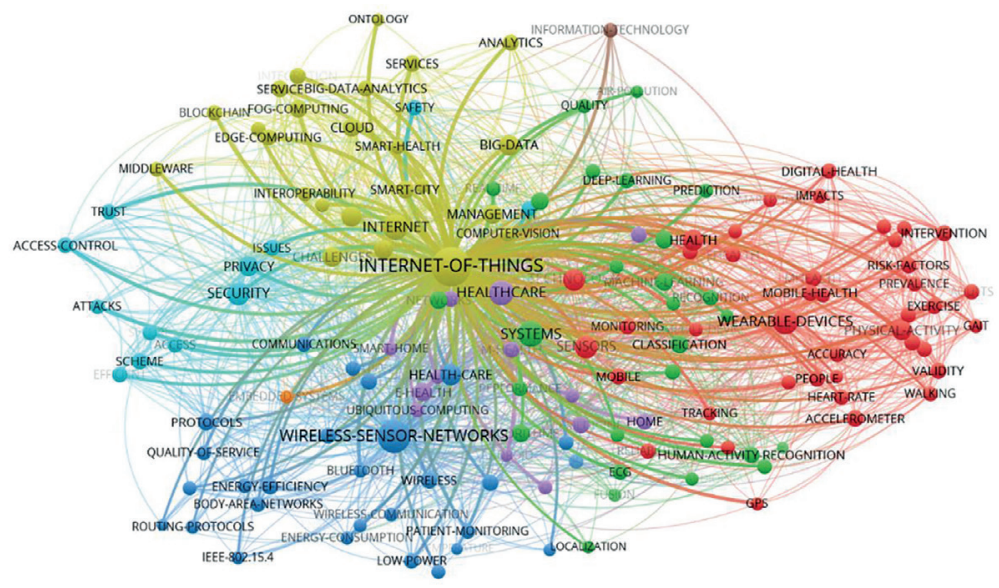

1. ábra: A jellemző kulcsszavak kapcsolati hálózata (saját ábra) 
A gráf segítségével vizualizált eredmény alapján láthatjuk az IoT- és a szenzorhálózatok központi szerepét, illetve a hozzájuk közvetlen kötődően fontosabb elemeket külön klaszterekbe rendezve. Az első klaszter olyan elemeket mutat be, mint a Big Data, a blockchain, a smart city (okosváros), a Smart Health (okos egészségügy) koncepció, a gépi látás és a menedzsment, ezt követően a második klaszter jellemző elemei közé tartozik a mélytanulás (deep learning), az elörejelzés, a gépi tanulás, az osztályozás és a tevékenységfelismerés, majd a harmadik klaszter kiegészíti az említetteket a hordható eszközökkel, a szenzorokkal (gyorsulásmérő és egyebek), az m-health koncepcióval, az intervencióval, a kockázati faktorokkal, a digitális egészségüggyel és a felügyelettel, míg a negyedik klaszter döntően a technológiai oldalt mutatja be a test területét érintő és általános szenzorhálózatokon keresztül a (vezeték nélküli) kommunikációs módszerek, az energiahatékonyság és a protokollok formájában. Kisebb klaszterként van jelen az okosotthon koncepció, ám hangsúlyosabb a biztonság kérdése külön klaszterben (1. ábra).

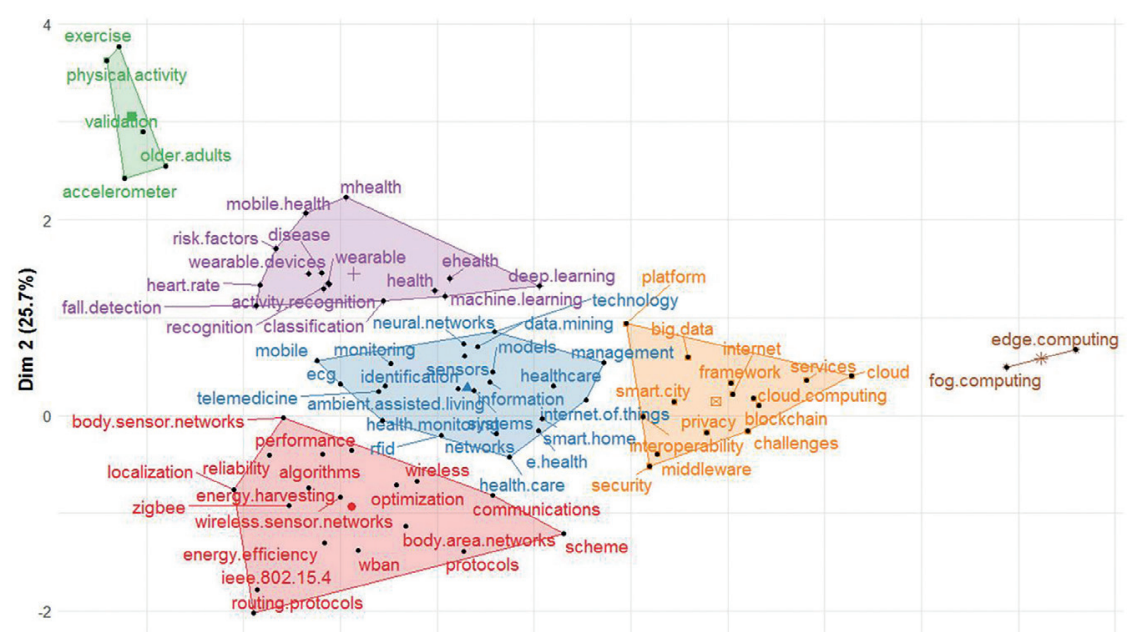

2. ábra: A területre jellemző klaszterek (saját ábra)

Az ezt követő elemzés során többszörös korrespondencia elemzés (MCA), majd k-közép klaszteranalízis került alkalmazásra, mely lehetővé teszi az egymáshoz közel álló területek lehatárolását. Az elemzés során sokkal inkább vagyunk kíváncsiak a domináns területekre (a hálózati elemzéssel ellenben), így a minimális kapcsolatot meghatározó küszöbérzék emelésre került 60-ra, csökkentve ezzel a jellemző elemszámot (2. ábra). Az elemzés során hat klaszter került meghatározásra. Az általuk reprezentált terület nehezen differenciálható, ám az elemek többségének figyelembevételével megkülönböztetjük a konkrét méréseket, a hordható eszközök lehetőségeit, illetve technikai tényezőit, a kettő között található elemzési lehetőségeket és koncepciókat, az adatkezelés (menedzsment) tényezőit, illetve a legkisebb klaszter a köd és peremszámítások koncepcióját írja le a decentralizált döntések megvalósítása és a folyamatos rendelkezésre állás érdekében. 
Az utolsó elemzés a tematikus evolúció, azaz a korábbi elemzések időtengelyre vetített változata, mely reprezentálja a területen felmerülő változásokat a kulcszszavak kapcsolatának aspektusában az egyes évekre vonatkozóan. Az évek és a kulcsszavak kapcsolatának vizualizálása alapján látható, hogy a domináns területek fokozott megjelenése 2009-re tehető, így az elemzés metszetének első pontját szintén ez képviseli, melyet szekvenciálisan 2011, 2013, 2015, 2016 és 2017, 2018 és 2019 követ. A bekerülés követelménye ezúttal 30 kapcsolatban került meghatározásra.

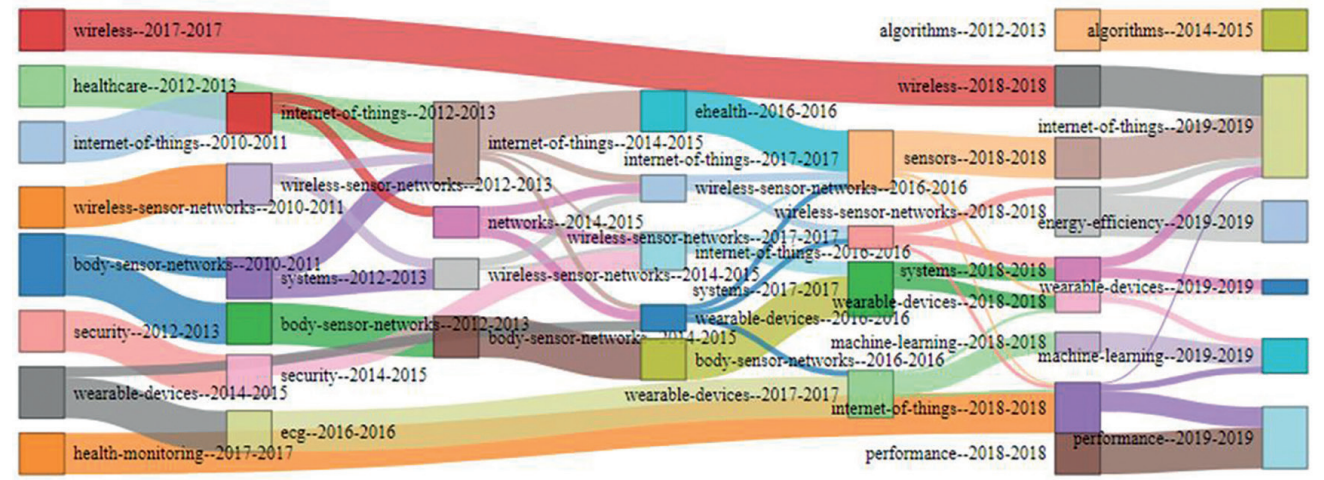

3. ábra: A terület kapcsolatainak változása (saját ábra)

Az eredmény Sankey-diagramon való ábrázolása által láthatjuk (3. ábra), a szenzorhálózatok átmenetét az összetettebb IoT-koncepcióba, mely közvetlenül kapcsolódik visszamenően az egészségügyhöz, illetve láthatjuk e témakör terjedését az e-health, a hordható eszközök és a test terültét érintő szenzorhálózatok felé. Ezenfelül aktuálisan láthatjuk a hordható eszközök fokozatos kapcsolódását a gépi tanulás területéhez.

\section{Anyag és módszer}

Mivel a kutatás döntően feltáró jellegű, több módszer került alkalmazásra a megfelelő eredmény elérése érdekében, ezzel igyekezve a technológia diffúzióját befolyásoló faktorok, illetve e faktorokat befolyásoló további tényezők megállapítására. A továbbiakban bemutatásra kerülnek a főbb módszerek az adatgyüjtés, az adatkezelés, illetve az adatelemzést illetően. Az adatgyüjtés egyedi kialakítású elektronikus kérdőív segítségével történik, míg az adatkezelés során számos, Big Data koncepció alapján definiált eljárás került alkalmazásra könnyebb kezelhetőség és a megfelelő struktúra kialakítása érdekében.

\section{Az adatgyüjtés módszere}

A primer adatgyűjtés kérdőíves felmérés segítségével került megvalósításra. A kérdőív CAWI-módszer alapján interneten került közzétételre, egyedi fejlesztésű alkal- 
mazás implementálásával, a kutatási részleteit bemutató aloldalon, ezzel növelve a kitöltő számára elérhető információt a területet illetően (hivatkozás az anonimitás érdekében ideiglenesen eltávolítva). A kérdőív öt, egymást szekvenciálisan követő és egymásra épülő komponensből tevődik össze, melyek sorra hivatottak demográfiai tényezőket, életmódot, adatgyüjtéssel kapcsolatos véleményt (IoT az egészségügyben) és adatelemzéssel kapcsolatos véleményt (Big Data az egészségügyben) mérni. Az ötödik komponens egyes ellenőrző változók segítségével végez mérést, mely kifejezi a vélemény esetleges változását az adatgyűjtésre vonatkozóan, miután a résztvevő szembesült az elérhető szolgáltatások előnyével a két szakasz között (kifejezve az információ hiányának hatását). Mivel sokak számára meglehetősen idegen területről van szó, a kérdések megfogalmazása során kiemelt figyelem összpontosult a piacon is elérhető eszközökön keresztül történő bemutatásra, ezenfelül minden szakmai jellegű szakasz egy bevezetéssel kezdődik, mely általános, összefoglaló képet ad a kitöltő részére igény szerint a jelenleg piacon, illetve kutatások formájában elérhető lehetőségeket illetően. További optimalizálás alapján a kérdőív előre meghatározott döntési fák segítségével redukálja és bővíti, illetve cseréli a kérdéseket, ezzel csökkentve a kitöltőre nehezedő terhet, figyelembe véve a kérdőív jelentős terjedelmét, melyre szükség volt a kutatás feltáró jellege miatt. Az egyes összetartozó kérdések (melyeket rendszerint egy adott válasz indukál) ugyanazon kérdésblokkban, a korábbi kérdés alatt jelennek meg az említett logika alapján, jelezve ezzel a logikai összetartozást. A döntési fát meghatározó szabályok szintén az adatbázisban kerülnek tárolásra mátrix formájában. A fontosabb technikai paramétereket bővítve megemlítendő, hogy a kérdőív motorja reszponzív elvet követve, támogatja a mobil eszközökön történő kitöltést, mellyel a jegyzések alapján éltek a kitöltők.

Az elemzések során alkalmazott minta két fő forrásból tevődött össze (n=229), melyből az első egyetemi hallgatókból ( $\mathrm{n}=51)$, míg a második véletlenszerűen kiválasztott kitöltőkből áll (n=178). A második csoport tagjai egy ismert közösségi hálózat marketingmódszereinek segítségével kerültek felkeresésre. A részvétel mindkét esetben önkéntes volt. A publikus adatgyüjtés időszaka 2019. december 20-a. és 2020. január 28-a. között volt esedékes.

\section{Alkalmazott módszerek}

Mivel a kérdőív döntően feltáró jellegű, fontos kérdés az adatok kezelése a gyors transzformálási lehetőségek biztosítása érdekében. Ennek megfelelően a kérdések és a válaszok mellett számos metaadatot tartalmazó adathalmaz került kialakításra, biztosítva ezzel a hierarchikus adatszerkezet megvalósulását (többindexes oszlopok segítségével). Az alkalmazott módszer lényegesen felgyorsította a különböző elemzésekhez és vizualizálási megoldásokhoz való alkalmazkodást, elősegítve ezzel az iteratív jellegű kötegelt elemzéseket, az optimális eredmény elérése és hatékonyabb módszerek keresése érdekében. Az indexek többek között tartalmazták a kérdés jellegét (általános vagy modellváltozó), a kérdés kategóriáját (demográfia, életmód, adatgyüjtés, adatelemzés, kontroll), a fő kérdés- vagy modellkonstruktor 
azonosítóját, illetve az adott változó azonosítóját. Mint az említésre került, a kérdőív öt fő komponensből tevődik össze, ezen belül megkülönböztetünk általános változókat és modellváltozókat (4. ábra). A modellváltozók esetében 5 szintes Likert-skála került alkalmazásra, mint az számos kutatás esetén jellemző a technológiai elfogadottságot mérő TAM- és UTAUT-modellek esetében (Holden és Karsh 2010).

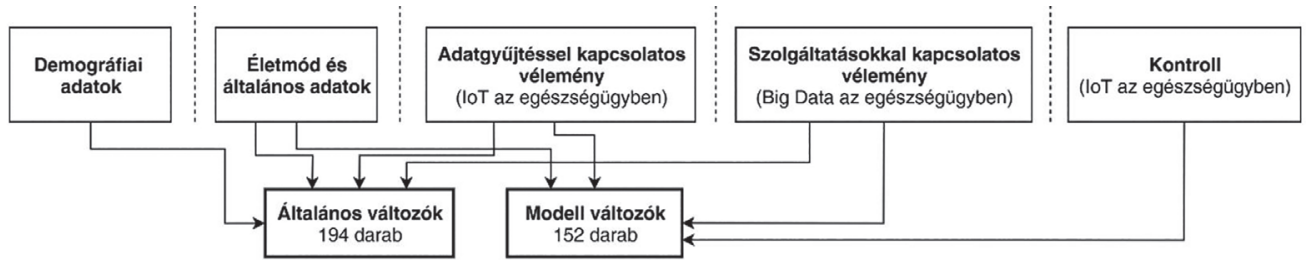

4. ábra: A kérdőív szerkezete (saját ábra)

Az adatok több szempont szerint kerültek szelektálásra, melybe beletartozik a túlzottan kiugró, irreális értékek (például: 900 éves kitöltő vagy $1 \mathrm{~cm}$ magas kitöltő), illetve a teljesen monoton válaszok (a teljes kérdőívre konstans értékkel reagált) törlése a teljes mintából.

Az átívelő összefüggések meghatározása a látens változók alkalmazásával, strukturális egyenletek modellezése segítségével történt. Összesen 31 látens változó került implementálásra, mely 151 mért változó által került meghatározásra, a UTAUT2-modell bővítése által. A kutatás során PLS-SEM (részleges legkisebb négyzetek) többváltozós módszer került alkalmazásra, amely ellenben a kovarianciaalapú CB-SEM-módszerrel, hatékonyan alkalmazható alacsonyabb elemszám és komplex struktúra mellett, a vele használt adatokra jellemző követelmények (például: eloszlás) igénye nélkül (Cassel, Hackl és Westlund 1999). A PLS-SEM képes az útvonalmodellben meghatározott parciális modellszerkezetek becslésére a főkomponenselemzés és legkisebb négyzetes regresszió kombinálásával. Célja a látens változók közötti kapcsolat megállapítása mért változók segítségével, illetve más aspektusból maximalizálja az endogén látens változók által magyarázott varianciát (Kao, Nawata és Huang 2019). A PLS-modellezés két lépcsőből áll, mely magában foglalja a látens változók pontozását, majd a strukturális és mérési modell paramétereinek becslését (Oom do Valle és Assaker 2016). Megkülönböztetünk megerősítő (hipotézisek tesztelése) és feltáró jellegű (mintázatok keresése) módszereket, melyek közül a PLS-SEM az utóbbihoz kötődik (Hair et al. 2013).

Egyes kutatások a teoretikus modelleket ordinális logisztikus regresszió segítségével vizsgálják az egészségügy területén (Handayani et al. 2018). A kutatás során a módszer hasonlóképp alkalmazásra került a demográfiai és az életmód egyes paramétereinek, az adatgyüjtésről és adatelemzésről alkotott véleményre kifejtett hatásának vizsgálata érdekében az érintett látens változók (mért változókon keresztül) figyelembevételével. Jelen kutatás során a proporcionális esély modell került alkalmazásra. 


\section{Eredmények és azok értékelése}

A kutatás célja a modern, egészségmegőrzést és aktivitást támogató (az IoT-koncepció alapján létrehozott, integrált jellegü) eszközökkel kapcsolatos tapasztalatok, illetve azok elterjedését befolyásoló faktorok vizsgálata, figyelembe véve az eszközök által gyüjtött adatok alapján igénybe vehető szolgáltatások használatából (az adatok kezelése és elemzése Big Data koncepció alapján) eredő esetleges előnyöket. Az eredmények döntően feltáró jellegű elemzésekből állnak össze, beleértve a minta leíró statisztikáját, az eszközöket és szolgáltatásokat érintő, egyénre vetített használati tényezőket, a használat motiváló tényezőit, az esetleges elhagyás indokait, továbbá a személyes preferenciákat az adatokra és mérésekre vonatkozó prioritásokat illetően, az adatgyüjtésre és az adatkezelésre vonatkozóan, az utóbbi esetében kiemelten kezelve az adatvédelem kérdését.

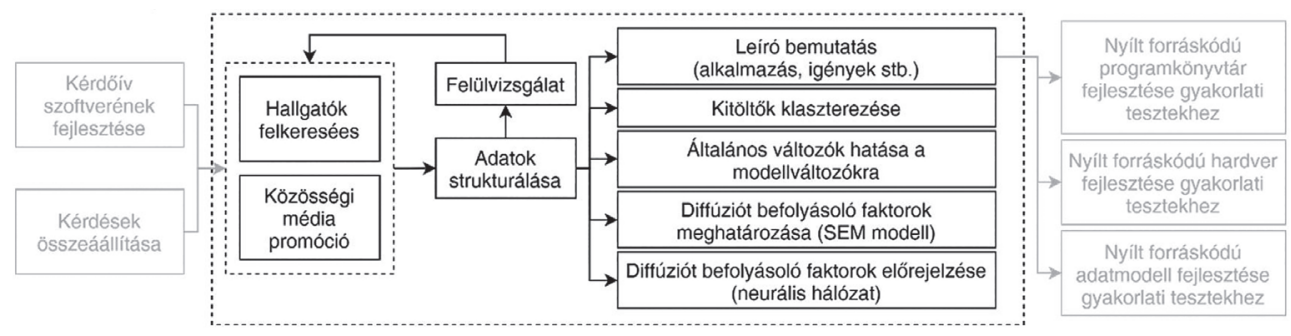

5. ábra: A bemutatásra kerülő lépések (saját ábra)

Az 5. ábra szemlélteti a teljes kutatást, illetve a jelenleg bemutatásra kerülő lépéseket. A továbbiakban a kérdőíves kutatásra helyeződik a hangsúly, ám a teljes folyamat áttekintése érdekében megemlítendő, hogy a bemutatásra kerülő eredmények alapján a kutatás folytatásaként kialakításra kerül egy nyílt forráskódú vezérlő, egy hozzá kapcsolódó programkönyvtár, illetve egy oktatási felületet, melynek célja a technológiára nyitott felhasználók, illetve start-up vállalkozások számára egy felhasználóbarát felület biztosítása a technológia lehetőségeinek tesztelése és koncepcióalkotás támogatása érdekében.

\section{A kérdőív kialakítása}

A kérdőív kialakítása kapcsán a technikai részletek (megjelenítési motor, adatbázis, adatstrukturálás és elemzések) már részben bemutatásra kerültek a módszertant leíró fejezetben, így a továbbiakban az alkalmazott változókra (konstruktorok, mért változók) fogunk koncentrálni. Mivel feltáró kutatásról beszélünk, nem fix, sokkal inkább iteratív elven változó teoretikus modell került kialakításra. Az alkalmazott konstruktorok központi részének implementálása a UTAUT2-modellből történt (Venkatesh, Thong és Xu 2012), mint az számos kutatás kapcsán jellemző volt, mivel annak egyik kimenete a viselkedési szándék, ám a területre jellemzően a mért változók módosításra kerültek 
a szakirodalomnak megfelelően. A területhez való alkalmazkodás érdekében további konstruktorokat is implementálni kellett. Összesen 31 látens változó mérése zajlott, melyből hét tekinthető a UTAUT2-modellhez, beleértve a PE (performance expectancy - várható teljesítmény), az EE (effort expectancy - várható erőfeszítés), az FC (faciliating conditions - támogató tényezők), a HM (hedonic motivation - hedonikus motiváció), az SI (social influence - közösségi befolyás), a PV (price value - ár és érték), illetve a BI (behavioral intention - viselkedési szándék). Az eredeti modell alapján az említett változók középpontjában a BI-változó szerepel, melynek eredményét az említett összes többi változó befolyásolja. Az eredeti modell tartalmazza az UB-változót (tényleges használat - use behavior) is, mely jelen esetben nem került implementálásra a technológia alkalmazásának alacsony aránya révén. A modellváltozók alapvetően az adatgyűjtő eszközökre vonatkoznak (a hordható eszközök, az asztali eszközök és a környezeti adatgyüjtő eszközök aspektusában), ám a BI- és FC-változó kiterjesztésre került az elemzési eszközök (szolgáltatások) témakörére a kérdőív ezzel kapcsolatos szakaszában, mivel azok jelen aspektusban az említett eszközök adatait dolgozzák fel, így a két témakör hatással van egymásra. Az UTAUT2-modellt alkotó eredeti változók, illetve kiegészítő változók az alábbi, 2. táblázatban jelölt források alapján kerültek összeállításra.

\begin{tabular}{|c|c|c|c|}
\hline Változó megnevezése & Változók száma & Kapcsolódó modell & Forrás \\
\hline $\begin{array}{l}\text { BI - Használati hajlan- } \\
\text { dóság }\end{array}$ & $2 * 8$ & UTAUT2 & $\begin{array}{l}\text { (Balapour et al. 2019; } \\
\text { Duarte és Pinho 2019; } \\
\text { Chang és Wu 2015) }\end{array}$ \\
\hline PE - Várható teljesítmény & $2 * 9$ & UTAUT2 & $\begin{array}{l}\text { (M. Zhang et al. 2017; } \\
\text { Nascimento, Oliveira és } \\
\text { Tam 2018; Gao, Li és Luo } \\
\text { 2015; Papa et al. 2018) }\end{array}$ \\
\hline EE - Várható erőfeszítés & 6 & UTAUT2 & $\begin{array}{l}\text { (Duarte és Pinho 2019; } \\
\text { Becker 2016) }\end{array}$ \\
\hline FC - Támogató tényezők & 8 & UTAUT2 & $\begin{array}{l}\text { (Duarte és Pinho 2019; Li } \\
\text { et al. 2019) }\end{array}$ \\
\hline $\begin{array}{l}\text { HM - Hedonikus moti- } \\
\text { váció }\end{array}$ & 4 & UTAUT2 & $\begin{array}{l}\text { (Duarte és Pinho 2019; } \\
\text { Weinhard, Hauser és } \\
\text { Thiesse 2017) }\end{array}$ \\
\hline SI - Közösségi hatás & 7 & UTAUT2 & (Duarte és Pinho 2019) \\
\hline HB - Szokás & 4 & UTAUT2 & $\begin{array}{l}\text { (Duarte és Pinho 2019; } \\
\text { Nascimento, Oliveira és } \\
\text { Tam 2018) }\end{array}$ \\
\hline PV - Ár-érték & 5 & UTAUT2 & $\begin{array}{l}\text { (Duarte és Pinho 2019; } \\
\text { Salinas Segura és Thiesse } \\
\text { 2015) }\end{array}$ \\
\hline SHC - Egészségi állapot & 3 & TAM, bövítve & (Li et al. 2019) \\
\hline $\begin{array}{l}\text { HBM - Egészségtuda- } \\
\text { tosság }\end{array}$ & 4 & Egyéni & (M. Zhang et al. 2017) \\
\hline $\begin{array}{l}\text { MTS - Mobil technológia } \\
\text { ismeretek }\end{array}$ & 3 & TAM és UTAUT & (Weng 2016) \\
\hline
\end{tabular}




\begin{tabular}{l|l} 
SNI - Közösségi média & 2 \\
hatása & 4 \\
SE - Önhatás & 5 \\
COM - Kompatibilitás & \\
PRI - Adatbiztonság & 3 \\
$\begin{array}{l}\text { PRC - Adatbiztonság } \\
\text { kétségek }\end{array}$ & 4 \\
PRS - Adatbiztonság & 3 \\
kockázatok & 3 \\
AES - Esztétika & 3 \\
BN - Márka & 3 \\
$\begin{array}{l}\text { PIP - Érzékelt pótolhatat- } \\
\text { lanság }\end{array}$ & 3 \\
RTC - Ellenállás a válto- \\
zásnak \\
$\begin{array}{l}\text { PSI - Érzékelt közösségi } \\
\text { kép }\end{array}$
\end{tabular}

$\begin{array}{ll}\begin{array}{l}\text { Egyéni } \\ \text { TAM, módosítva }\end{array} & \begin{array}{l}\text { (Cheung et al. 2019) } \\ \text { UTAUT2, TAM }\end{array} \\ \text { Egyéni } & \begin{array}{l}\text { (Chang és Wu 2019) } \\ \text { al. Li et }\end{array} \\ \text { Egyéni } & \text { (Rupp et al. 2018) } \\ \text { UTAUT, módosítva } & \text { (Marakhimov és Joo 2017) } \\ \text { Egyéni } & \text { (Y. Zhang et al. 2019) } \\ \text { UTAUT, módosítva } & \text { (Jeong et al. 2017) } \\ \text { Egyéni } & \text { (Yang et al. 2016) } \\ \text { UTAUT, módosítva } & \text { (M. Zhang et al. 2017) } \\ \text { Egyéni } & \text { (Hoque és Sorwar 2017) } \\ \text { UTAUT2, módositva } & \text { (Talukder et al. 2019) } \\ \end{array}$

\section{2. táblázat: Az alkalmazott konstruktorok}

A 6. ábra alapján látható a modell előzetes kialakítása, figyelembe véve az elképzelés szerint vélhetően fix pozícióban lévő, illetve a mozgatható vagy kizárható változókat. A $P E$-, $E E$-, $S I$-, $F C$-, $H M$-, $P V$-, $H M$-, illetve a $B I$-változók és azok kapcsolata képezi a UTAUT2-modell alapjait, míg a további változók az említett kiegészítés eredményeiként vannak jelen. A továbbiakban e változók hierarchikus kapcsolatával kerül meghatározásra a modell megfelelő szerkezete.

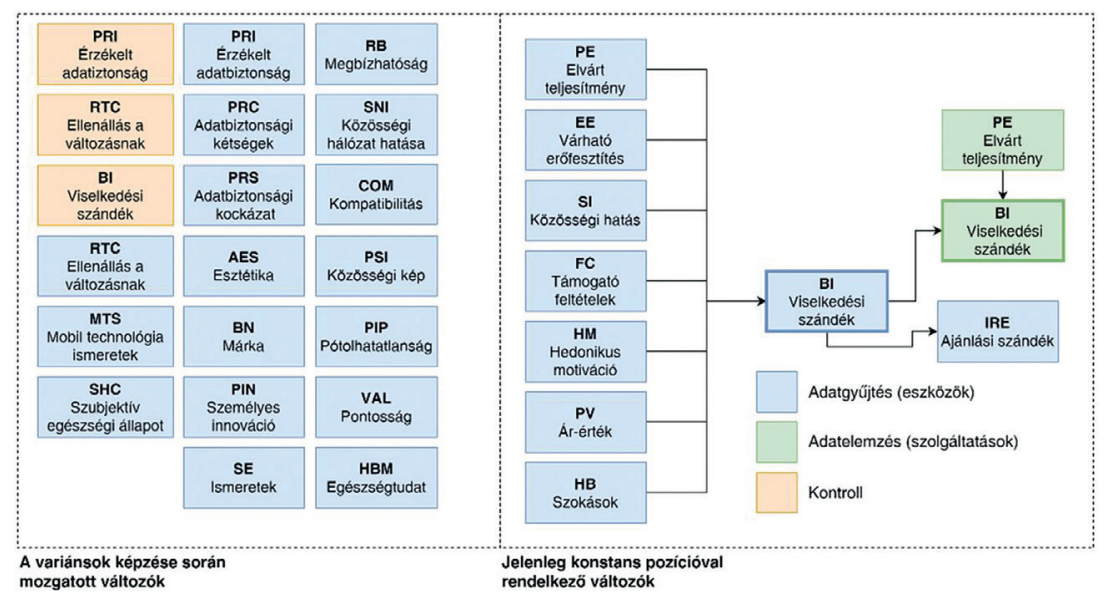

6. ábra: A modell előzetes struktúra (saját ábra) 
A kialakítás során hasonlóan más kutatásokhoz (Baudier, Ammi és Deboeuf-Rouchon 2018) a BI-változót (behavior intention - viselkedési szándék) befolyásoló faktorok meghatározása mellett további cél megállapítani, hogy a UTAUT2-modell változói milyen faktorok által kerülnek befolyásolásra. Ennek megfelelően nem a szakirodalomban definiált UTAUT2-modell módosításáról beszélünk, sokkal inkább annak kiegészítéséről, tényezőinek magyarázásáról.

\section{A résztvevők demográfiája}

A kutatásban résztvevők számos aspektusból elemezhetők a rendelkezésre álló változók segítségével. Az eredmények összesítését, illetve az említett adattisztítást követően a részvevők száma $n=229$ fő. Az elemszám meghatározása során szűk keresztmetszetet a PLS-SEM-modell követelményei jelentették, mely megállapítása érdekében több megközelítés is rendelkezésre áll. Egyes kutatások alapján (Thompson, Higgins és Howell 1994) a megközelítő elemszám meghatározása során egy adott látens változót magyarázó hatások tízszeresének értékét ajánlott figyelembe venni, mely alapján jelen esetben a kritikus elemszám $n=100$ rekord lenne (10 kapcsolatot figyelembe véve), ám a G*Power (Faul et al. 2007) priori számítása alapján $n=226$ rekord számít kritikusnak 90\% megbízhatósági szint mellett, mely feltáró kutatás esetén elfogadható (Conroy 2015), különösen a területre jellemzően. Az eredmény 30 prediktor alkalmazása esetén tekinthető relevánsnak, ám az összes látens változó kis valószínűséggel kerül felhasználásra, így kevesebb elemszám is megfelelőnek tekinthető, a kialakított modell komplexitásának függvényében. A mintára jellemző, nemre és korra vetített eloszlás az alábbi, 7. ábrán látható.
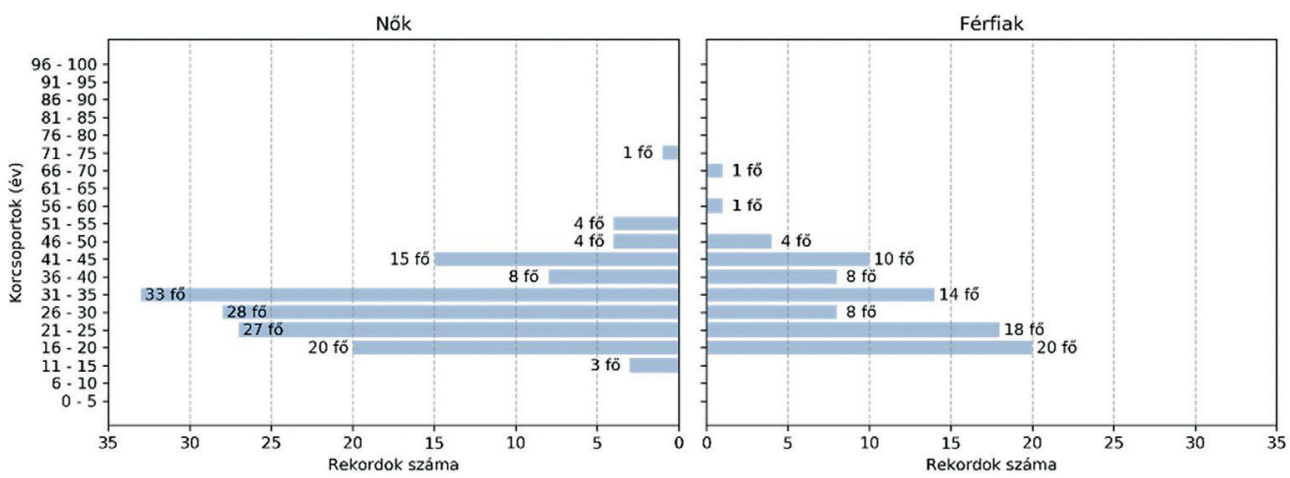

7. ábra: A résztvevőkre jellemző populációs piramis (saját ábra)

A mintában dominálnak a 16 és 35 év közötti résztvevők (168 fő - 73\%), illetve a nők (143 fő - 62\%). További demográfiai adatokat figyelembe véve értékelendő a korábbi és aktuális oktatás (DE5, DE6, DE9), illetve a foglalkozás (DE7) és a munkakör (DE8) kérdése. Végzettség tekintetében a résztvevők többsége (109 résztvevő) középiskolai végzettséggel rendelkezik, melyet az alapképzés aránya követ (45 résztvevő). 

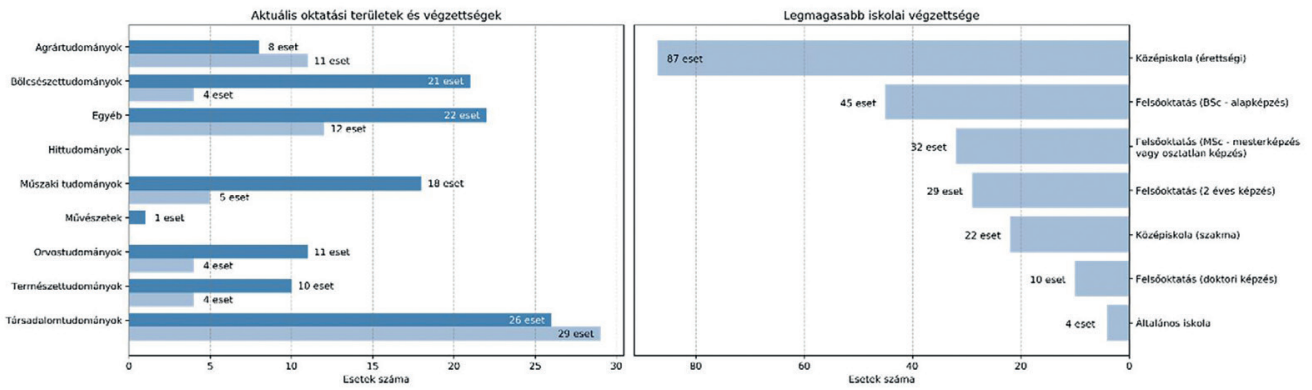

8. ábra: Tanulmányok és tudományterületek (saját ábra)

Felsőoktatási tanulmányait 69 résztvevő végezte a kitöltés idején. A résztvevők között 80 fő állt kapcsolatban a Debreceni Egyetemmel korábbi vagy jelenlegi tanulmányai alatt. Tudományterületet szerint a döntő többség (jelenlegi oktatás és korábbi végzettség alapján) társadalomtudományokhoz sorolta tanulmányait (55 fő), melyet az egyéb kategória (39 fő) és bölcsészettudományok (25 fő) követnek (8. ábra). A résztvevők közül 111 fő jelezte, hogy jelenleg teljes munkaidőben dolgozik, míg arányait követve a második legnagyobb csoportot a tanulók vagy hallgatók jelentették 70 főt számlálva (DE7). A munkakört tekintve döntő többségben a diplomás alkalmazottak vannak a teljes vagy részmunkaidőben dolgozók halmazában jelen 48 fővel, melyet a szakalkalmazottak aránya követ 27 fővel (9. ábra).

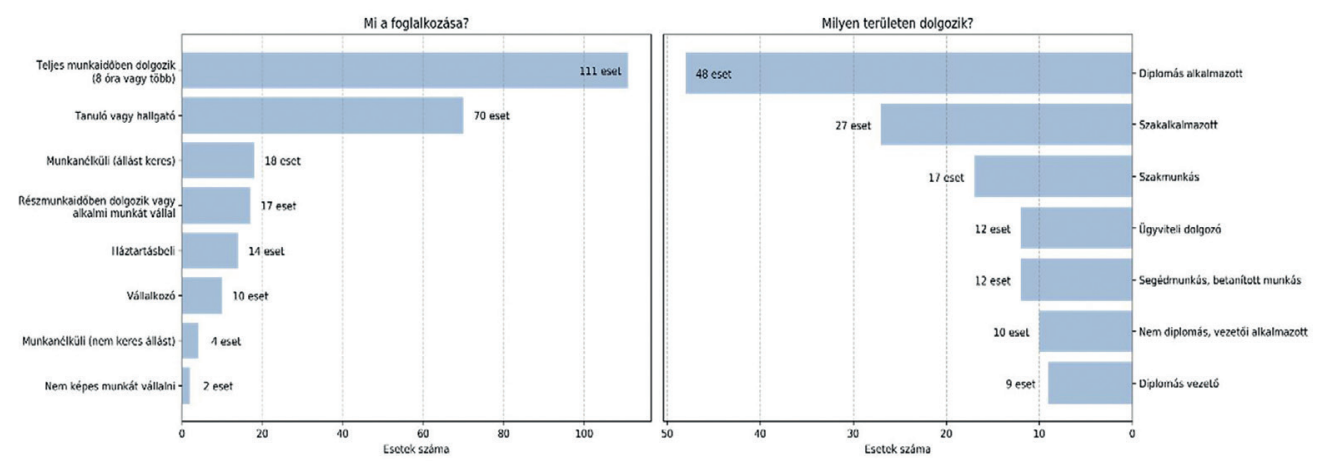

9. ábra: Foglalkozás és munkakör (saját ábra)

\section{A résztvevők véleménye és igényei}

További paraméterként került mérésre a résztvevők korábbi tapasztalata a technológiát érintően, külön kezelve az adatgyűjtés (hordható, asztali és környezeti eszközök) és adatelemzés (nyilvántartás és mesterséges intelligencián alapuló szolgáltatások) aspektusát. Az adatgyűjtést érintően jellemző eszközök és azok résztvevőkkel való viszonya a 10. ábra segítségével került vizualizálásra. Az adatok alapján látható, hogy legtöbben telefonos lépésszámlálóval rendelkeznek (158 
fő), melyet az okos asztali eszközök (47 fö), illetve okosórák (44 fő) tulajdonosai követnek. E halmazon belül a tényleges alkalmazás aránya $85 \%$ és $83 \%$ volt. A legalacsonyabb érdeklődés az okosruházat felé irányult, mely kapcsán 84 fő ismeri a technológiát, ám nem érdeklődik iránta, míg 60 fő nem ismeri a technológiát, ám nem is fejezi ki érdeklődését iránta. Azon résztvevők között, akik legalább egy eszközzel rendelkeznek (összesen 173 fő), 12 fő kevesebb, mint egy hónapja, 27 fő több mint egy hónapja, de kevesebb mint egy éve, 67 fő több mint egy éve, de kevesebb mint három éve, illetve szintén 67 fő több mint három éve szerezte be első eszközét a felsoroltak közül.

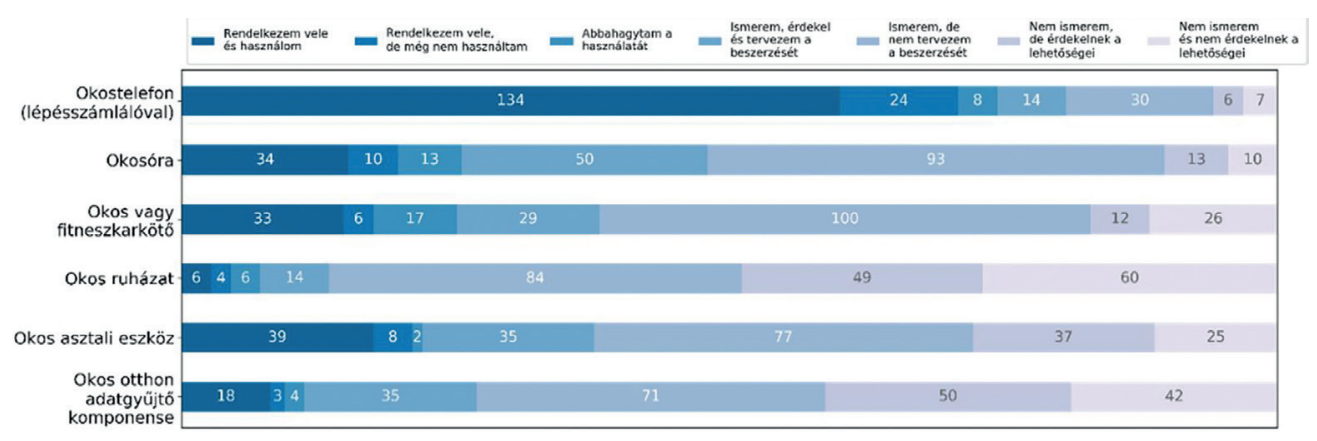

10. ábra: Az eszközök és felhasználók kapcsolata (fő) (saját ábra)

A pozitív motivációs faktorok kapcsán meghatározásra kerültek azon tényezők, melyek elősegítették a vásárlási hajlandóságot, illetve az elvárások teljesítése révén fokozhatják annak bekövetkezését. Mindkét változó esetében több elem is meghatározásra kerülhetett a résztvevők által. Az alkalmazásra irányuló motivációs tényezőt leginkább a kíváncsiság (116 eset), az egészségtudatosság (101 eset) és az edzés vagy sporttevékenység támogatásának igénye (81 eset) jelentette, míg a mérlegelés és motiváló tényezők között az ár (171 eset), a minőség (169 eset) és a pontosság (129 fő) állnak. E tényezők közül egyes faktorok (az ár, a pontosság és a márka) a strukturális modellbe is implementálásra kerülnek látens változóként mérve, kifejezve ezzel a döntéshozatalban betöltött esetleges szerepüket (11. ábra).

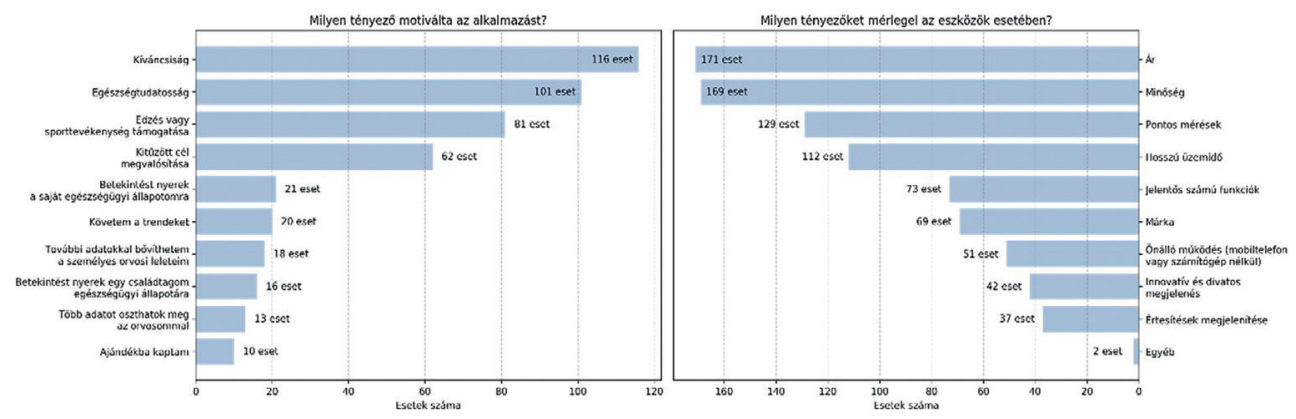

11. ábra: Motivációs tényezők az eszközök használatát illetően (saját ábra) 
Negatív motivációs faktorként az elhagyás (használat felfüggesztése), illetve az ellenállás (érdeklődés hiánya) egyes tényezői kerültek meghatározásra. Az első halmaz 52 esetből, míg a második 330 esetből áll, mivel több tényező is kiválasztásra kerülhetett a kitöltés során. Az alkalmazást gátló fő tényezők között szerepel a magas ár (104 fő), illetve a motiváció hiánya (66 fő). Az adatvédelmi megfontolás az egyik utolsó helyen szerepel (7fö), ám - mint azt látni fogjuk a későbbiekben - ez a tényező hatással van a használati hajlandóságra (12. ábra).
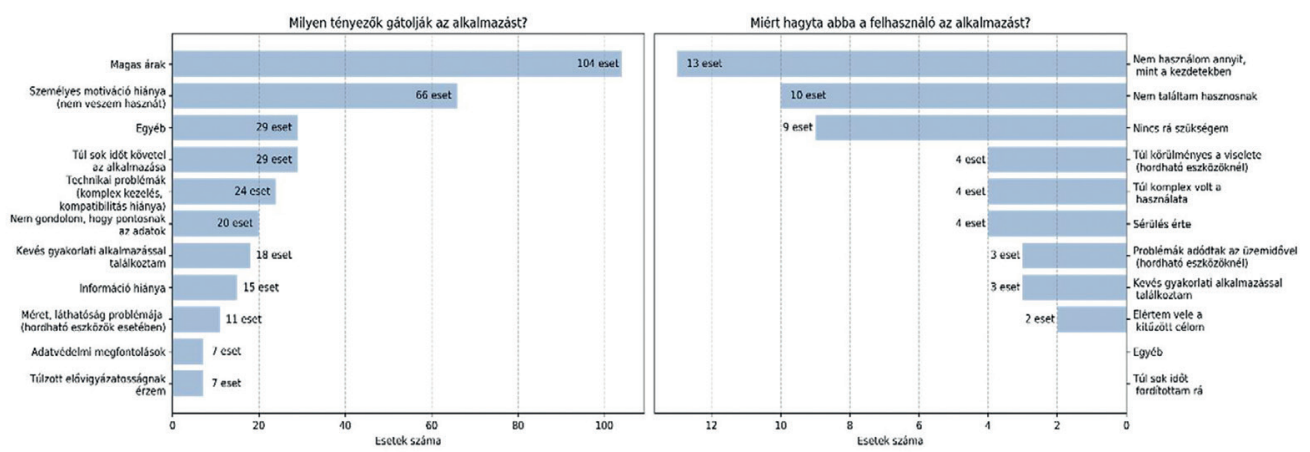

12. ábra: Negatív tényezők az eszközök használatát illetően (saját ábra)

A használat során kiemelten fontos az elvárt vitális paraméterek kérdése (13. ábra), hiszen e tényező jelentősen meghatározza az alkalmazásra kerülő eszközöket. A felmérés során megállapításra kerül, hogy szubjektív vélemény alapján a résztvevők mely paramétereket tekintik fontosnak ( $A D G Y 11$ ), illetve e tényezőket milyen eszközzel (hordható vagy asztali) mérnének inkább (ADGY16), mely az alternatíva választásának lehetőség révén szintén hatással lehet az attitűdre. A kimagaslóan fontos és fontos kategóriák összegét tekintve lenagyobb súllyal a vérnyomás, a pulzus és a szívritmus mérése szerepel, melyek közül a vérnyomás 200 esetben került jegyzésre fontos vagy magasabb kategóriába.

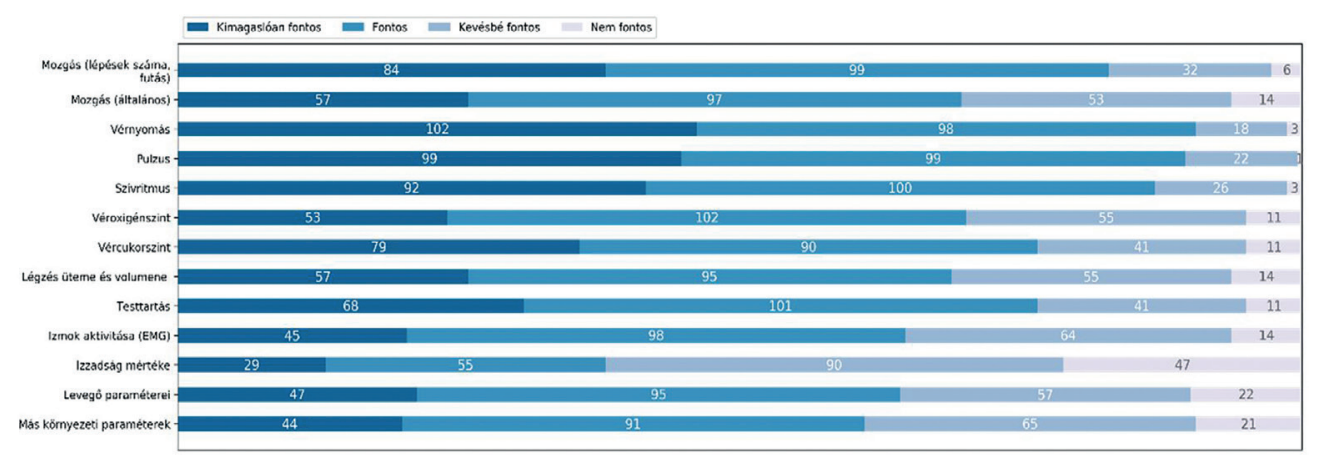

13. ábra: Az egyes mérhető paraméterek fontosságának értékelése 
A továbbiakban az adatok alkalmazására vonatkozó lehetőségek kerülnek bemutatásra a felhasználók preferenciájának figyelembevételével, kiemelve az előbb említett eszközök által gyüjtött adatok különböző - rendszerint közvetett - folyamatokon történő alkalmazását. Az területen jellemző alkalmazások és szolgáltatások résztvevőkkel való kapcsolata az 14. ábra segítségével kerül bemutatásra az adatgyưjtéshez hasonlóan. Látható, hogy a résztvevők több mint fele (56\%) méri valamilyen eszköz segítségével a lépések számát (mint legismertebb alternatíva), míg kicsivel kevesebb mint fele (49\%) a megtett távolságot és sebességet. Az adatok tényleges felhasználásának részaránya a lépésszámot tekintve magasabb (80\%). A legkisebb arányban a stressz szintje kerül mérésre a résztvevők által, mely érthető a jellemző megoldások komplexebb mivolta révén.

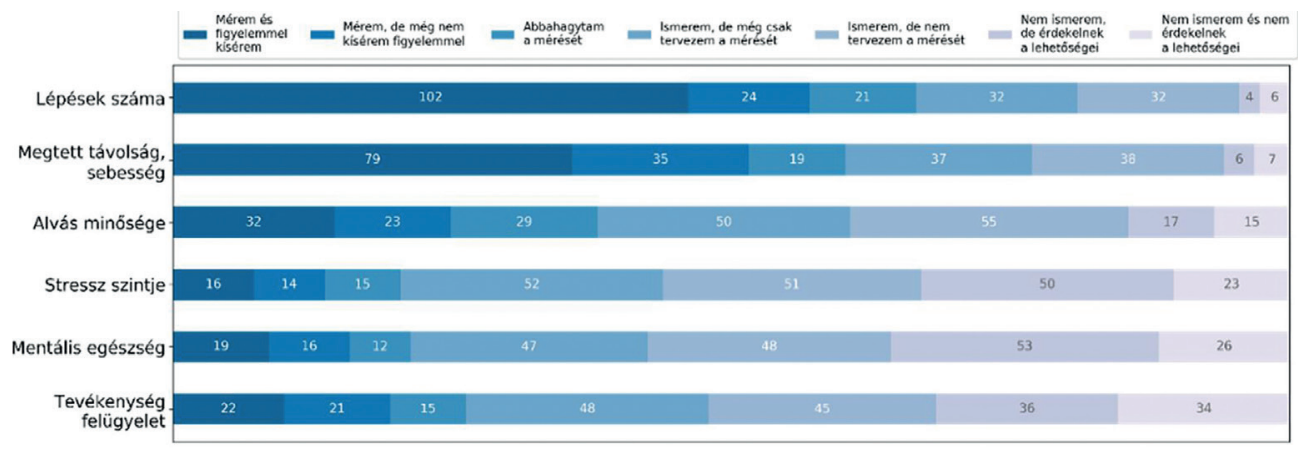

14. ábra: Az eszközök és szolgáltatások kapcsolata (fő) (saját ábra)

Az adatgyüjtéssel és adatelemzéssel kapcsolatos preferenciák a 15. ábrán láthatók (15. ábra). Mivel egyes szolgáltatások az adatok megosztását igénylik, fontos szempont az erre vonatkozó hajlandóság mérése. Az adatok megosztásának pozitív megítéléssel illetett céljai között magas részarányban szerepel a személyre szóló tanácsadás (103 eset), az orvosi diagnózis támogatása (83 eset), illetve a betegségek előrejelzése (83 eset). Az adatok fogadójaként 136 esetben kerültek megjelölésre orvosok, melyek a családtagok követnek 93 jelölt esettel.

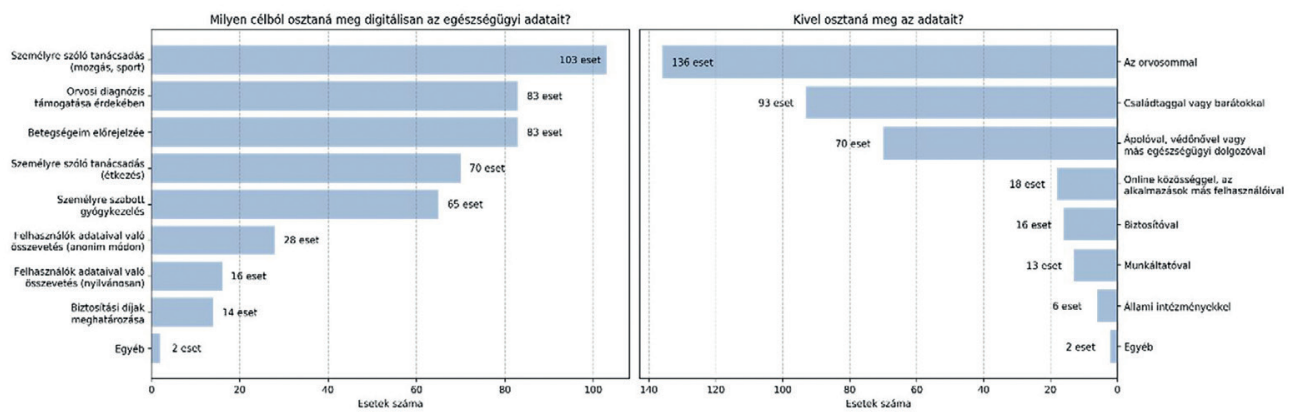

15. ábra: Az adatok megosztásának kérdései (saját ábra) 
Az adatok megosztását támogató résztvevők között 113 esetben támogatták a vitális paraméterek (pulzus, vérnyomás, vércukorszint stb.), 112 esetben a fitnesz adatok (lépésszám, alvásminőség stb.), míg 57 esetben a digitalizált orvosi leletek megosztását előrejelző és előíró algoritmusok támogatása érdekében.

A befolyásoló tényezők meghatározása strukturális modell segítségével

A strukturális egyenletek modellezése segítségével meghatározásra kerülnek a szignifikáns útvonalak, befolyásolva a végkimenetelt képező BI-változó (behavior intention - viselkedési szándék) alakulását, mely esetünkben a használati hajlandóságot hivatott kifejezni. Mielőtt megtörténne az elemzés, szükséges a modellhez kapcsolódó változók alkalmasságának vizsgálata, melyre szükség van a PLS-SEM követelményeinek való megfelelés érdekében, illetve mivel egyes módszerek esetében nincs lehetőség a látens változót alkotó mért változók súlyozott figyelembevételére (mint e módszer esetében jellemző). Ennek megfelelően szükséges a látens változók konzisztenciájának ellenőrzése annak érdekében, hogy lehetőség nyíljon a mért változók individuális alkalmazására is a későbbiekben, reprezentálva ezzel a látens változó által mért faktort. A tesztek elvégzése előtt felülbírálás révén eltávolításra került három konstruktor, beleértve a PRC (privacy concern-adatvédelmi kétségek), a PRS (privacy risk - adatvédelmi veszélyek), illetve az SHC (self reported health conditions - egészségügyi állapot) változókat, mivel azok részben vagy teljes egészében inverz skálán kerültek mérésre és a kimutatások alapján e tényezőt a résztvevők egy része nem vette megfelelően figyelembe, ezzel torzítva az eredményt.

Mindenekelőtt individuálisan ellenőrzésre kerültek a látens változót alkotó mért változók VIF (Variance Inflation Factor - varianciainflációs tényező) értékek segítségével a multikollinearitás kiküszöbölése érdekében. Egyes kutatások alapján a multikollinearitás nem feltétlen rontja a regresszió pontosságát (O’Brien 2007), emellett reflektív modellek esetében nem okoznak problémát (a külső modellt érintően), így először csak jelölésre kerülnek a kritériumnak nem megfelelő változók, mely a külső modell esetében hét darab volt. A belső modellt vizsgálva a VIF értékek minden esetben a küszöbérték alatt maradtak, figyelembe véve egy kiugró (VIF=4,39), de még küszöbérték alatt elhelyezkedő értéket a $B I$ - és $H B$-változó között, így a modell eredményét feltehetően nem befolyásolja a multikollinearitás problémája. Ezt követően belső konzisztencia, illetve konvergens és diszkriminatív érvényességet kimutató számítások kerültek alkalmazásra, a mérési modell reflektív jellegére való tekintettel. A belső konzisztencia kapcsán a Cronbach alfa mutató esetében a követelményt $(\alpha>0,6)$ minden konstruktor teljesítette $p<0,001$ szignifikancia szint mellett (Churchill Jr 1979). A Dijkstra-Henseler-féle rho indikátor esetében a jellemző irányelvet $(\rho>0,7)$ szintén minden konstruktor teljesítette (Ariza-Monte et al. 2019) $p<0,001$ szignifikancia szint mellett. A konvergens validitás vizsgálata érdekében megállapításra kerül (3. táblázat), hogy a különböző mért változók az adott látens változót egységesen határozzák meg. Ennek megállapítása érdekében faktorsúly, emellett kompozit megbízhatóság és AVE (Average Variance Extracted - átlagos kivonatolt variancia) mutatók kerültek kiszámításra. Az AVE mutató esetében a megfelelő tartomány $A V E>0,5$ érték, mely kifejezi, hogy a konstruktor egésze 50\%-ban fejezi ki a konstruktort alkotó mért változók varianciáját (Hair et al. 2019). Az SE (önhatás - self-efficacy) változó esetében két mért változó (SE3, SE4) törlésre került (a faktor- 
súlyok alapján), az előbbiekhez hasonlóan a részben inverz skálán történő mérésből eredő pontatlanság révén. A szakirodalom alapján a mért változókat csak akkor érdemes eltávolítani, ha az nem rontja az magyarázóképességet, így egyes változók az alacsony faktorsúly ellenére is a modell részei maradtak. A HBM (health beliefegészségtudat) esetében törlésre került egy mért változó (HBM2) a tényleges jelentés fordításának nehézségeiből eredő problémák kiküszöbölése érdekében. A felsorolt értékek minden esetben $p<0,001$ szignifikancia szint mellett teljesültek, kivéve az $R T C$-változó (resistance to change - ellenállás a változásnak) esetén jellemző rho indikátor, melynek eredménye nem szignifikáns $(p=0,638)$, ám a további, e módszer esetében aktuálisabb mutatók súlya mellett ez nem jelent problémát. A faktorsúlyok esetében a legrosszabb érték 0,548 volt (HBM1), ám a szakirodalom alapján a konzisztencia megőrzése érdekében csak >0,5 érték esetén érdemes a változó kizárását mérlegelni (Hair et al. 2019).

\begin{tabular}{|c|c|c|c|c|c|c|}
\hline & Átlag & Szórás & $\begin{array}{l}\text { Cronbach- } \\
\text { alfa }\end{array}$ & rho & $\begin{array}{l}\text { Kompozit } \\
\text { megbízhatóság }\end{array}$ & AVE \\
\hline AES - Esztétika & 3,75 & 0,91 & 0,897 & 0,897 & 0,896 & 0,742 \\
\hline $\begin{array}{l}\text { BI - Viselkedési szándék } \\
\text { (adatelemzés) }\end{array}$ & 3,63 & 1,12 & 0,969 & 0,970 & 0,969 & 0,797 \\
\hline $\begin{array}{l}\text { BI - Viselkedési szándék } \\
\text { (adatgyüjtés) }\end{array}$ & 3,66 & 1,12 & 0,960 & 0,963 & 0,961 & 0,726 \\
\hline BN - Márka & 3,66 & 1,02 & 0,914 & 0,923 & 0,915 & 0,730 \\
\hline COM - Kompatibilitás & 3,66 & 1,01 & 0,906 & 0,907 & 0,904 & 0,655 \\
\hline EE - Várható erőfeszítés & 4,10 & 0,92 & 0,937 & 0,939 & 0,939 & 0,718 \\
\hline FC - Támogató tényezők & 4,02 & 1,01 & 0,914 & 0,923 & 0,916 & 0,579 \\
\hline HB - Szokás & 3,74 & 0,97 & 0,895 & 0,895 & 0,895 & 0,740 \\
\hline HBM - Egészségtudat & 4,48 & 0,82 & 0,735 & 0,769 & 0,748 & 0,503 \\
\hline $\begin{array}{l}\text { HM - Hedonikus moti- } \\
\text { váció }\end{array}$ & 3,56 & 1,09 & 0,930 & 0,931 & 0,929 & 0,767 \\
\hline IRE - Ajánlás szándéka & 3,45 & 1,17 & 0,880 & 0,898 & 0,879 & 0,711 \\
\hline $\begin{array}{l}\text { MTS - Mobil technológia } \\
\text { ismeretek }\end{array}$ & 4,13 & 0,97 & 0,867 & 0,881 & 0,869 & 0,691 \\
\hline $\begin{array}{l}\text { PE - Várható teljesít- } \\
\text { mény }\end{array}$ & 3,77 & 0,99 & 0,953 & 0,954 & 0,954 & 0,720 \\
\hline $\begin{array}{l}\text { PE - Várható teljesít- } \\
\text { mény (adatelemzés) }\end{array}$ & 3,83 & 0,98 & 0,961 & 0,962 & 0,961 & 0,754 \\
\hline PIN - Személyi innováció & 3,58 & 1,14 & 0,884 & 0,888 & 0,882 & 0,500 \\
\hline $\begin{array}{l}\text { PIP - Észlelt pótolhatat- } \\
\text { lanság }\end{array}$ & 3,77 & 0,94 & 0,844 & 0,863 & 0,843 & 0,646 \\
\hline $\begin{array}{l}\text { PRC - Érzékelt adatbiz- } \\
\text { tonsági kétségek* }\end{array}$ & 3,32 & 1,15 & 0,942 & $-3,99$ & - & - \\
\hline $\begin{array}{l}\text { PRS - Érzékelt adatbiz- } \\
\text { tonsági veszélyek* }\end{array}$ & 3,40 & 1,11 & 0,898 & 1,576 & 1,002 & 1,004 \\
\hline
\end{tabular}




\begin{tabular}{|c|c|c|c|c|c|c|}
\hline $\begin{array}{l}\text { PRI - Észlelt adatbiz- } \\
\text { tonság }\end{array}$ & 3,44 & 1,10 & 0,899 & 0,905 & 0,901 & 0,753 \\
\hline $\begin{array}{l}\text { PSI - Észlelt közösségi } \\
\text { kép }\end{array}$ & 3,00 & 1,17 & 0,938 & 0,939 & 0,938 & 0,782 \\
\hline PV - Ár-érték & 3,21 & 1,06 & 0,907 & 0,908 & 0,906 & 0,660 \\
\hline RB - Reliability & 3,78 & 0,87 & 0,918 & 0,919 & 0,918 & 0,737 \\
\hline $\begin{array}{l}\text { RTC - Ellenállás a válto- } \\
\text { zásnak }\end{array}$ & 2,98 & 1,17 & 0,925 & 0,946 & 0,923 & 0,742 \\
\hline SE - Önhatékonyság & 3,45 & 1,33 & 0,890 & 0,901 & 0,894 & 0,809 \\
\hline $\begin{array}{l}\text { SHC - Szubjektív egész- } \\
\text { ségi állapot** }\end{array}$ & 3,71 & 1,06 & 0,767 & 0,945 & 0,755 & 0,551 \\
\hline SI - Közösségi hatás & 3,23 & 1,19 & 0,912 & 0,928 & 0,915 & 0,688 \\
\hline $\begin{array}{l}\text { SMI - Közösségi média } \\
\text { hatása }\end{array}$ & 3,09 & 1,22 & 0,933 & 0,939 & 0,932 & 0,639 \\
\hline VAL - Validitás & 3,84 & 0,83 & 0,902 & 0,902 & 0,901 & 0,752 \\
\hline
\end{tabular}

3. táblázat: Belső konzisztencia és konvergens validitás (saját számítások)

A diszkriminatív validitás értelmében meghatározásra kerül, hogy a konstruktorok egyértelműen megkülönböztethetők egymástól. A szakirodalom alapján a validitás e formája két módszer segítségével állapítható meg, beleértve a konstruktorokra jellemző AVE értékek összevetését a konstruktorokra jellemző korrelációs együtthatók négyzetével (az előbbinek nagyobbnak kell lennie), illetve alternatív módszerként a mért változók súlyának nagyobbnak kell lennie a konstruktoron belül, mint a külső konstruktorokra fejtett hatás. Egyes kutatások alapján az előbb említett mérőszámok nem minden esetben mutatják ki a diszkriminatív validitás hiányát, így a HTMT-módszer (heterotrait-monotrait ratio of correlations) alkalmazását javasolják (4. táblázat). A számítások alapján az összes konstruktor megfelelt a küszöbértéknek (HTMT<0,9), így a diszkriminatív validitás teljesült a reflektív konstruktorok között (Dijkstra és Henseler 2015).

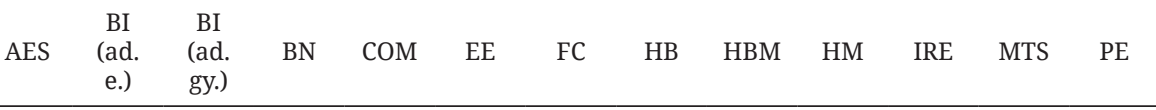

\begin{tabular}{l|llllllllll}
\hline $\begin{array}{l}\text { BI } \\
\text { (ad.e.) }\end{array}$ & 0,552 & & & & & & & \\
$\begin{array}{l}\text { BI } \\
\text { (ad.gy.) }\end{array}$ & 0,640 & 0,861 & & & & & & & \\
BN & 0,691 & 0,353 & 0,449 & & & & & & \\
COM & 0,624 & 0,712 & 0,804 & 0,457 & & & & & \\
EE & 0,558 & 0,502 & 0,616 & 0,431 & 0,734 & & & & \\
FC & 0,572 & 0,555 & 0,641 & 0,429 & 0,800 & 0,835 & & & \\
HB & 0,684 & 0,751 & 0,815 & 0,433 & 0,874 & 0,627 & 0,684 & & \\
HBM & 0,252 & 0,324 & 0,330 & 0,236 & 0,375 & 0,435 & 0,373 & 0,361 & \\
HM & 0,594 & 0,486 & 0,611 & 0,374 & 0,630 & 0,473 & 0,492 & 0,641 & 0,277
\end{tabular}




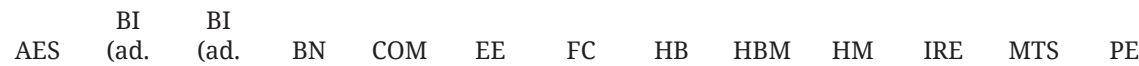
e.) gy.)

\begin{tabular}{l|lllllllllllllll}
\hline IRE & 0,540 & 0,800 & 0,842 & 0,421 & 0,634 & 0,490 & 0,495 & 0,652 & 0,165 & 0,508 & & & \\
MTS & 0,336 & 0,408 & 0,369 & 0,371 & 0,511 & 0,651 & 0,549 & 0,422 & 0,252 & 0,271 & 0,305 & & \\
PE & 0,676 & 0,766 & 0,885 & 0,484 & 0,762 & 0,601 & 0,661 & 0,843 & 0,319 & 0,634 & 0,719 & 0,386 & \\
PE & 0,592 & 0,872 & 0,764 & 0,401 & 0,686 & 0,474 & 0,550 & 0,740 & 0,354 & 0,527 & 0,696 & 0,363 & 0,802 \\
PIN & 0,622 & 0,676 & 0,722 & 0,506 & 0,767 & 0,693 & 0,709 & 0,749 & 0,245 & 0,630 & 0,651 & 0,526 & 0,736 \\
PIP & 0,683 & 0,559 & 0,638 & 0,523 & 0,578 & 0,510 & 0,536 & 0,660 & 0,259 & 0,548 & 0,496 & 0,255 & 0,655 \\
PRI & 0,486 & 0,555 & 0,598 & 0,427 & 0,670 & 0,585 & 0,542 & 0,593 & 0,187 & 0,441 & 0,592 & 0,414 & 0,595 \\
PSI & 0,506 & 0,397 & 0,453 & 0,412 & 0,434 & 0,345 & 0,323 & 0,428 & 0,126 & 0,580 & 0,486 & 0,294 & 0,489 \\
PV & 0,447 & 0,460 & 0,520 & 0,483 & 0,648 & 0,496 & 0,499 & 0,566 & 0,230 & 0,524 & 0,475 & 0,356 & 0,471 \\
RB & 0,605 & 0,611 & 0,694 & 0,518 & 0,656 & 0,590 & 0,586 & 0,693 & 0,173 & 0,481 & 0,570 & 0,334 & 0,735 \\
RTC & 0,137 & 0,120 & 0,096 & 0,196 & 0,063 & 0,079 & 0,109 & 0,041 & 0,093 & 0,200 & 0,102 & 0,105 & 0,114 \\
SE & 0,442 & 0,486 & 0,463 & 0,308 & 0,654 & 0,753 & 0,799 & 0,578 & 0,326 & 0,350 & 0,401 & 0,581 & 0,515 \\
SI & 0,499 & 0,422 & 0,487 & 0,489 & 0,506 & 0,385 & 0,443 & 0,499 & 0,287 & 0,466 & 0,491 & 0,241 & 0,478 \\
SMI & 0,507 & 0,492 & 0,516 & 0,432 & 0,532 & 0,392 & 0,437 & 0,529 & 0,224 & 0,561 & 0,607 & 0,304 & 0,502 \\
VAL & 0,636 & 0,586 & 0,652 & 0,516 & 0,580 & 0,556 & 0,559 & 0,649 & 0,270 & 0,443 & 0,550 & 0,353 & 0,713
\end{tabular}

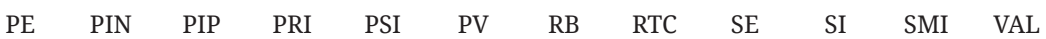

\begin{tabular}{l|llllllllllll}
\hline PIN & 0,684 & & & & & & & & & \\
PIP & 0,577 & 0,645 & & & & & & & & \\
PRI & 0,517 & 0,652 & 0,484 & & & & & & & \\
PSI & 0,370 & 0,557 & 0,449 & 0,529 & & & & & & \\
PV & 0,411 & 0,628 & 0,473 & 0,571 & 0,631 & & & & & & \\
RB & 0,618 & 0,702 & 0,623 & 0,658 & 0,411 & 0,553 & & & & & \\
RTC & 0,149 & 0,129 & 0,089 & 0,090 & 0,452 & 0,380 & 0,045 & & & \\
SE & 0,498 & 0,517 & 0,388 & 0,532 & 0,214 & 0,358 & 0,489 & 0,056 & & \\
SI & 0,435 & 0,534 & 0,408 & 0,457 & 0,688 & 0,591 & 0,425 & 0,325 & 0,337 & & \\
SMI & 0,487 & 0,534 & 0,450 & 0,436 & 0,696 & 0,611 & 0,414 & 0,317 & 0,320 & 0,751 & \\
VAL & 0,614 & 0,652 & 0,645 & 0,546 & 0,350 & 0,402 & 0,821 & 0,043 & 0,442 & 0,395 & 0,379
\end{tabular}

\section{4. táblázat: A HTMT értékek (saját számítások)}

A továbbiakban kialakításra került a strukturális modell az egyes tényezők együttes hatásának vizsgálata érdekében. Egy tipikus SEM munkafolyamat öt fő részből áll, beleértve a modell specifikációt, azonosítást, becslést, tesztelést és módo- 
sítást (Schumacker és Lomax 2015). Mint azt a szakirodalom esetében is láthattuk, számos kutatás alkalmazza a UTAUT2-modellt hordható eszközök és a digitalizált egészségügy aspektusában, így alapvetően pozitív eredmény volt várható. A kiegészítő változók közül a kizárt változóktól eltekintve mind beépítésre került, a logikai következetességet követve. A UTAUT2-modell struktúráját megőrizve a kiegészítő változók új hierarchiai szinten foglalnak helyet, ezzel a UTAUT2 változókra való hatásukat vizsgálva. Az első futtatás során nem került moderátor változó alkalmazásra. A modell eredményeinek számítása során 8000 iteráció került alkalmazásra az útszámítás és a szignifikancia tesztelése érdekében használt bootstrap mintavétel során egyaránt.

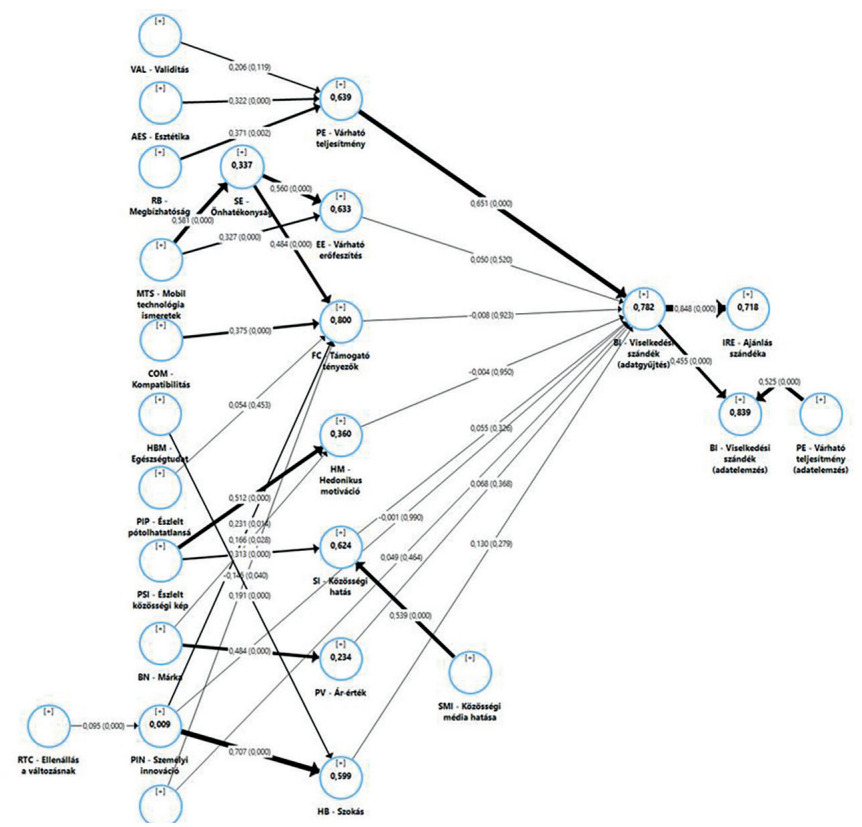

16. ábra: Az alkalmazott modell útvonalai (saját ábra)

Az első variáns megoldását követően láthatjuk (16. ábra), hogy a legerősebb hatással rendelkező faktornak a $P E$-változó (performance expectancy - várható teljesítmény) tekinthető 0,639 koefficiens ( $p>0,001)$ mellett, melyet a $H B$-változó (habit - szokás) követ, 0,130 koefficiens mellett, ám az utóbbi nem tekinthető szignifikánsnak. Az eredmény a területen mondhatni nem idegen (Tavares és Oliveira 2018; Duarte és Pinho 2019), melynek céljából kerültek alkalmazásra a kiegészítő változók. A PE-változó kifejezi, hogy az adott technológia alkalmazása növelheti az egyed teljesítményét (Venkatesh et al. 2003). Kutatások kiemelik a PE (performance expectancy - várható teljesítmény) és EE-változók (effort expectancy - várható erőfeszítés) szerepét a technológia elfogadottság vizsgálata esetében (Kijsanayotin, Pannarunothai és Speedie 2009). A PE-változó jellegéből adódóan egységesnek tekinthető (véleményt illetően), ugyanis a résztvevők preferenciái talán kevésbé befolyásolják, hogy mit várnak el egy eszköztől, szemben a további változókkal. Az említett $E E$-változó 
a TAM-modellben alkalmazott PEU-változóval (perceived ease of use - érékelt használati könnyedség) ekvivalens és közvetlenül kifejezi a technológia komplexitását a felhasználó szemszögéből (Venkatesh, Thong és Xu 2012). Az FC-változó (facilitating conditions - támogató tényezők) azon tényezőket foglalja össze, melyek támogathatják az alkalmazást, beleértve szervezeti és technikai tényezőket (Kijsanayotin, Pannarunothai és Speedie 2009). Az összefüggés hiánya utalhat a résztvevők technikai felkészültségére, vagy arra a feltételezésre, hogy a megfelelő technikai ellátottság nem feltétlen eredményezi a jelen kutatás tárgyát képező technológiai megoldások diffúzióját. A HM (hedonic motivation - hedonikus motiváció) az új technológiából származó élvezeti értéket reprezentálja (Cho és Park 2016). A hatás hiánya szintén magyarázható az termékek és szolgáltatások céljával, miszerint használatukkal sokkal inkább az egyes előnyök elérése a cél. Az SI-változó (social influence - közösségi hatás) a barátok, családtagok, kollégák hatását jeleníti meg (Venkatesh, Thong és Xu 2012). Egyes kutatások kiemelkedő szerepet tulajdonítanak a tényezőnek, ám jelen mintán nem mutatkozott szignifikáns kapcsolat. A $P V$-változó (price value - ár érték) reprezentálja az észlelt előnyök és a pénzköltségek közötti kompromisszumot (Venkatesh, Thong és Xu 2012). E vélemény számos oldalról befolyásolásra kerülhet (jövedelem, attitűd stb.), így jelen kontextusban nem meglepő a magas eltérés. Több változó esetében találkozhatunk külső tényezők befolyásoló hatásával, melyek hatással lehetnek a változók közötti kapcsolatra, így a későbbiekben vissza fogunk térni rá adott esetek megfogalmazásával. A részletes eredmények, beleértve a kiegészítő változók szerepét, az 5. táblázat segítségével kerültek kifejtésre.

\begin{tabular}{|c|c|c|c|c|c|}
\hline & Útegyüttható & $\begin{array}{l}\text { Útegyüttható } \\
\text { átlaga }\end{array}$ & $\begin{array}{l}\text { Útegyüttható } \\
\text { szórása }\end{array}$ & \multirow{2}{*}{ t-érték } & \multirow{2}{*}{ p-érték } \\
\hline & Eredeti minta & \multicolumn{2}{|l|}{$\begin{array}{l}\text { Bootstrap } \\
\text { minta }\end{array}$} & & \\
\hline $\mathrm{AES} \rightarrow \mathrm{PE}$ & 0,322 & 0,324 & 0,071 & 4,419 & 0,000 \\
\hline $\begin{array}{l}\text { BI (adatgyűjtés) } \rightarrow \text { BI } \\
\text { (adatelemzés) }\end{array}$ & 0,455 & 0,468 & 0,098 & 4,652 & 0,000 \\
\hline BI (adatgyűjtés) $\rightarrow$ IRE & 0,848 & 0,848 & 0,033 & 25,828 & 0,000 \\
\hline $\mathrm{BN} \rightarrow \mathrm{HM}$ & 0,166 & 0,167 & 0,075 & 2,202 & 0,028 \\
\hline $\mathrm{BN} \rightarrow \mathrm{PV}$ & 0,484 & 0,485 & 0,076 & 6,332 & 0,000 \\
\hline $\mathrm{COM} \rightarrow \mathrm{FC}$ & 0,375 & 0,376 & 0,101 & 3,723 & 0,000 \\
\hline $\mathrm{EE} \rightarrow \mathrm{BI}$ (adatgyűjtés) & 0,050 & 0,048 & 0,078 & 0,643 & 0,520 \\
\hline FC $\rightarrow$ BI (adatgyűjtés) & $-0,008$ & $-0,006$ & 0,085 & 0,096 & 0,923 \\
\hline HB $\rightarrow$ BI (adatgyűjtés) & 0,130 & 0,129 & 0,120 & 1,084 & 0,279 \\
\hline $\mathrm{HBM} \rightarrow \mathrm{HB}$ & 0,191 & - & - & - & - \\
\hline HM $\rightarrow$ BI (adatgyűjtés) & 0,004 & 0,005 & 0,071 & 0,063 & 0,950 \\
\hline $\mathrm{MTS} \rightarrow \mathrm{EE}$ & 0,327 & 0,328 & 0,078 & 4,190 & 0,000 \\
\hline $\mathrm{MTS} \rightarrow \mathrm{SE}$ & 0,581 & 0,584 & 0,060 & 9,661 & 0,000 \\
\hline
\end{tabular}




\begin{tabular}{|c|c|c|c|c|c|}
\hline & Útegyüttható & $\begin{array}{l}\text { Útegyüttható } \\
\text { átlaga }\end{array}$ & $\begin{array}{l}\text { Útegyüttható } \\
\text { szórása }\end{array}$ & \multirow{2}{*}{ t-érték } & \multirow{2}{*}{ p-érték } \\
\hline & Eredeti minta & \multicolumn{2}{|l|}{$\begin{array}{l}\text { Bootstrap } \\
\text { minta }\end{array}$} & & \\
\hline $\mathrm{PE} \rightarrow \mathrm{BI}$ (adatgyűjtés) & 0,651 & 0,650 & 0,104 & 6,284 & 0,000 \\
\hline $\begin{array}{l}\text { PE (adatelemzés) } \rightarrow \text { BI } \\
\text { (adatelemzés) }\end{array}$ & 0,525 & 0,512 & 0,099 & 5,305 & 0,000 \\
\hline PIN $\rightarrow$ BI (adatgyűjtés) & 0,001 & 0,002 & 0,107 & 0,013 & 0,990 \\
\hline $\mathrm{PIN} \rightarrow \mathrm{FC}$ & 0,231 & 0,227 & 0,094 & 2,447 & 0,014 \\
\hline $\mathrm{PIN} \rightarrow \mathrm{HB}$ & 0,707 & - & - & - & - \\
\hline $\mathrm{PIP} \rightarrow \mathrm{FC}$ & 0,054 & 0,054 & 0,072 & 0,751 & 0,453 \\
\hline PRI $\rightarrow$ BI (adatgyűjtés) & 0,049 & 0,050 & 0,067 & 0,733 & 0,464 \\
\hline $\mathrm{PRI} \rightarrow \mathrm{FC}$ & $-0,145$ & $-0,145$ & 0,071 & 2,054 & 0,040 \\
\hline $\mathrm{PSI} \rightarrow \mathrm{HM}$ & 0,512 & 0,510 & 0,075 & 6,868 & 0,000 \\
\hline $\mathrm{PSI} \rightarrow \mathrm{SI}$ & 0,313 & 0,311 & 0,086 & 3,532 & 0,000 \\
\hline $\mathrm{PV} \rightarrow \mathrm{BI}$ (adatgyűjtés) & 0,068 & 0,067 & 0,075 & 0,900 & 0,368 \\
\hline $\mathrm{RB} \rightarrow \mathrm{PE}$ & 0,371 & 0,369 & 0,121 & 3,081 & 0,002 \\
\hline $\mathrm{RTC} \rightarrow \mathrm{PIN}$ & 0,095 & - & - & - & - \\
\hline $\mathrm{SE} \rightarrow \mathrm{EE}$ & 0,560 & 0,557 & 0,074 & 7,570 & 0,000 \\
\hline $\mathrm{SE} \rightarrow \mathrm{FC}$ & 0,484 & 0,488 & 0,087 & 5,560 & 0,000 \\
\hline SI $\rightarrow$ BI (adatgyűjtés) & 0,055 & 0,053 & 0,056 & 0,982 & 0,326 \\
\hline $\mathrm{SMI} \rightarrow \mathrm{SI}$ & 0,539 & 0,543 & 0,078 & 6,905 & 0,000 \\
\hline $\mathrm{VAL} \rightarrow \mathrm{PE}$ & 0,206 & 0,208 & 0,132 & 1,560 & 0,119 \\
\hline
\end{tabular}

\section{5. táblázat: Az útegyütthatók áttekintése (saját számítások)}

A kiegészítő változók között több szignifikáns kapcsolatot figyelhetünk meg, beleértve az AES (asthetics - esztétika) és a $R B$ (reliability - megbízhatóság) kapcsolatát a $P E$-változóval (várható teljesítmény). Az említett két változón túl alkalmazott $V A L$-változó (validity - validitás) hatása nem bizonyult szignifikánsnak. Az AES-változó definíciója alapján a fogyasztók a fejlett technológia mellett, egy hordható eszköz esetében nem akarják elveszteni divatérzéküket (Jeong et al. 2017), míg az $R B$-változó kifejezi, hogy az eszköz konzisztens szinten tud müködni életciklusa alatt (Rupp et al. 2018). Az MTS-változó (mobile technology self-efficacy - mobil technológia önismeret) szignifikáns hatással van az EE-változóra (effort expectancy - várható erőfeszités), illetve a $S E$-változóra (self efficacy - önhatás), ezzel kifejezve, hogy a technológia ismeretek pozitív hatással vannak az egyes problémák megoldására és az alkalmazkodásra. Az SE-változó (self efficacy - önhatás) ezenfelül szignifikáns hatással van az FC-változóra (faciliating conditions - támogató tényezők), mely szintén kifejezi az ismeretek pozitív hatását, mint támogató tényező. A COM-változó (compatibility - kompatibilitás) szignifikáns hatással van az FC-változóra, mely kifejezi, hogy 
az adott termék vagy szolgáltatás használatának hasonlósága hétköznapi eszközökhöz (például mobiltelefon), illetve a mindennapokba való beilleszthetőség támogató tényezőként van jelen (Li et al. 2019). A HBM-változó (health belief-egészségtudat) szignifikáns hatással van a $H B$-változóra (habit-szokás), melyből az előbbi kifejezi a résztvevő beavatkozási készségét egészségügyi probléma esetén ( $M$. Zhang et al. 2017). A PSI-változó (perceived social image - érzékelt közösségi kép) szignifikáns hatással van a HM- (hedonic motivation - hedonikus motiváció) és SI-változókra (social influence - közösségi hatás). A PSI-változó magas értéke esetén a résztvevő tudatosan alakítja ki társadalmi képét, illetve viselkedésével igyekszik másokat „lenyűgözni” viselkedésével (Jeong et al. 2017), mely hozzájárulhat a köztudatban kevésbé ismert eszközök vásárlásához. A $B N$ (brand - márka) szignifikáns hatással van a $H M$ - és $P V$-változóra. A márkanév egyes kutatások alapján a fogyasztók egyik legfontosabb külső jele egyes termékek értékelésére (Dawar és Parker 1994). A PRI-változó (privacy-adatbiztonság) bár nem mutat szignifikáns kapcsolatot egy konstruktorral sem, ám hatását mégis érezteti, mint azt látni fogjuk a későbbiekben.

A modellben előforduló indirekt effektusok között az AES (aesthetics - esztétika) és a $R B$ (reliability - megbízhatóság) $\beta=0,210$ és $\beta=0,242$ hatással van a $B I$ (adatgyüjtés) és $\beta=0,096$ és $\beta=0,110$ hatással van a $B I$-változóra (adatelemzés) $\mathrm{p}<0,001$ szignifikancia szint mellett, míg ugyanezen változók $\beta=0,178$ és $\beta=0,205$ hatással vannak az IRE-változóra (intention to recommend-ajánlás szándéka).

A modellben szereplő endogén változók és a rájuk jellemző többszörös determinációs együttható értéke a 6. táblázatban került összefoglalásra, mely alapján láthatjuk, hogy a különböző eszközökre irányuló szándék (a $B I$-változó adatgyűjtés variánsa) 78,2\%-ban magyarázható, ám további problémaként értékelem a magyarázó változók számát. A HB (habit - szokás) és a PIN (personal innovativeness - személyi innováció) esetében hiányos adathalmaz révén nem sikerült szignifikanciaszintet számolni, így relevanciájától eltekintünk.

\begin{tabular}{|c|c|c|c|c|c|}
\hline & Koeff. & Koeff. átlaga & Koeff. szórása & \multirow[b]{2}{*}{ t-érték } & \multirow[b]{2}{*}{ p-érték } \\
\hline & Eredeti minta & $\begin{array}{l}\text { Bootstrap } \\
\text { minta }\end{array}$ & & & \\
\hline $\begin{array}{l}\text { BI - Viselkedési szándék } \\
\text { (adatelemzés) }\end{array}$ & 0,839 & 0,845 & 0,034 & 24,584 & 0,000 \\
\hline $\begin{array}{l}\text { BI - Viselkedési szándék } \\
\text { (adatgyűjtés) }\end{array}$ & 0,782 & 0,798 & 0,037 & 21,219 & 0,000 \\
\hline EE - Várható erőfeszítés & 0,633 & 0,638 & 0,084 & 7,512 & 0,000 \\
\hline FC - Támogató tényezők & 0,800 & 0,812 & 0,038 & 20,862 & 0,000 \\
\hline HB - Szokás & 0,599 & - & - & - & - \\
\hline $\begin{array}{l}\text { HM - Hedonikus moti- } \\
\text { váció }\end{array}$ & 0,360 & 0,367 & 0,064 & 5,599 & 0,000 \\
\hline IRE - Ajánlás szándéka & 0,718 & 0,720 & 0,055 & 12,980 & 0,000 \\
\hline $\begin{array}{l}\mathrm{PE} \text { - Várható teljesít- } \\
\text { mény }\end{array}$ & 0,639 & 0,648 & 0,047 & 13,530 & 0,000 \\
\hline
\end{tabular}




\begin{tabular}{|c|c|c|c|c|c|}
\hline & Koeff. & Koeff. átlaga & Koeff. szórása & \multirow[b]{2}{*}{ t-érték } & \multirow[b]{2}{*}{ p-érték } \\
\hline & Eredeti minta & $\begin{array}{l}\text { Bootstrap } \\
\text { minta }\end{array}$ & & & \\
\hline PIN - Személyi innováció & 0,009 & - & - & - & - \\
\hline PV - Ár-érték & 0,234 & 0,241 & 0,073 & 3,192 & 0,001 \\
\hline SE - Önhatékonyság & 0,337 & 0,345 & 0,070 & 4,819 & 0,000 \\
\hline SI - Közösségi hatás & 0,624 & 0,631 & 0,055 & 11,426 & 0,000 \\
\hline
\end{tabular}

6. táblázat: Determinációs együtthatók (saját számítások)

A BI-változóhoz (behavior intention - viselkedési szándék) közvetlenül kapcsolódó látens változók magyarázóképességének javítása érdekében érdemes az adatok további áttekintésével foglalkozni, mely rávilágíthat azon tényezőkre, melyek magyarázzák az átlagtól való eltérést. Az adatok hierarchikus strukturálásának köszönhetően a regresszió - és minden más elemzés - teljesen automatizálható, így lehetőség van az elemzések iteratív elvégzésére, elősegítve ezzel a kutatást. Figyelembe véve, hogy a PLS-módszer alapvetően lineáris kapcsolatot feltételez (kivéve egyes módszerek), lineáris regresszió került alkalmazásra, ám az átlagtól való jelentős eltérés miatt RANSAC-módszerrel, mely hatékonyan képes ezen értékek figyelembevételére. Az áttekintés feltáró jellege miatt a mért változók átlagolásra kerültek, a súlyozások figyelmen kívül hagyásával. Amennyiben megvizsgáljuk a UTAUT2-modell fő változói és a BI-változó közötti kapcsolatot, láthatjuk, hogy a pontok a változóra jellemzően adott irányba térnek el a lineáris kapcsolattól, azaz a maradványértékek adott irányba növekednek, illetve láthatjuk, hogy a $P E$-változó illeszkedése tekinthető legpontosabbnak, mint ahogy az az útegyüttható alapján is látható volt.
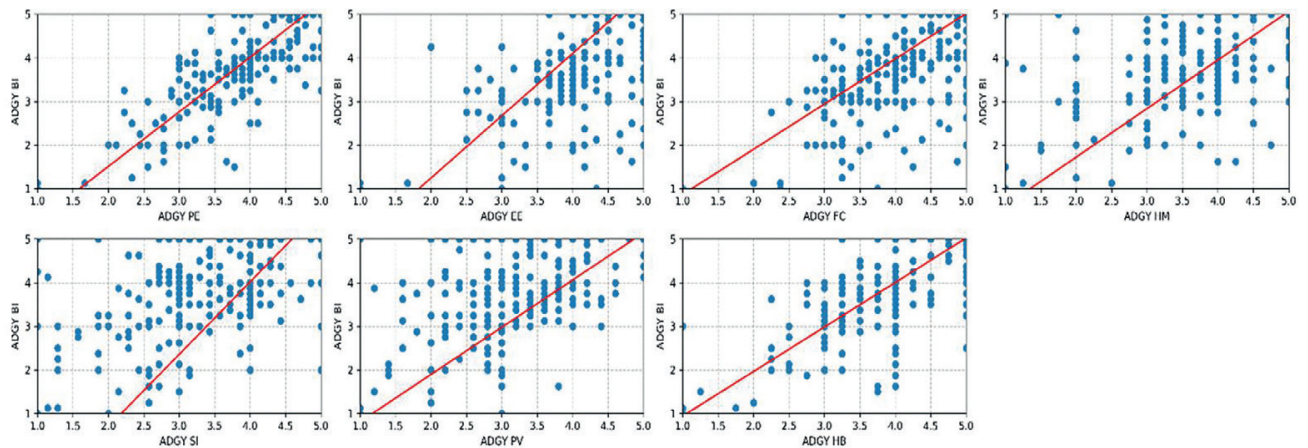

17. ábra: Lineáris regresszió a BI-változó és a további UTAUT2-változók között (saját ábra)

A 17. ábra alapján az adathalmazra jellemző lehet a nem megfigyelt heterogenitás jelenléte, mely a mintára jellemző alcsoportok között felmerülő jelentős különbséget takarja valamilyen paraméter mentén (Hair et al. 2013). Hasonló hatással 
lenne egy nemlineáris kapcsolat jelenléte, ám ez kevésbé jellemző a mintázat alapján. A magyarázóképesség javítása érdekében érdemes az adatok csoportosításával foglalkozni, mely rávilágíthat azon tényezőkre, amelyek magyarázzák a szélsőséges véleményformálást a $B I$-változó és a további UTAUT2-modellhez tartozó változók között. E lépés fontosnak tekinthető, mivel egyes, potenciálisan a véleményt befolyásoló tényezők nem kerülnek mérésre a modellt alkotó változók segítségével, így előfordulhat, hogy a modellen kívül álló más tényező befolyásolja az eredményt. A továbbiakban a modell esetleges fejlesztése érdekében a cél olyan moderátor vagy csoportosító változó keresése az általános változók között, melyek hatást gyakorolnak a modellben szereplő további változókra. A UTAUT2-modell által definiált változók (életkor, nem és tapasztalat) nem bizonyultak megfelelő megoldásnak. Lehetséges megoldás a FIMIX-eljárás (finite mixture) használata a csoport szegmentációja érdekében, vagy egy megfelelő moderátorváltozó keresése. Az előbbinek célja a belső modellben fennálló heterogenitás megszüntetése az egyes megfigyelések adott szegmenshez való tartozásának becslésével, mely folyamat közben a koefficiensek becslése is megtörténik (Hahn et al. 2002). E módszerre épülhet a PLS-POS-eljárás (Prediction-Oriented Segmentation), mely klaszterezési megközelítést alkalmaz a megfigyelések csoportokhoz való determinisztikus hozzárendeléséhez iteratív elven, majd a távolságok alapján azok újbóli hozzárendelésére (Squillacciotti 2010). Mindkét módszer alkalmazásra került a kutatás során, bár a PLS-POS-módszer esetében túlzott szegmentálás volt érezhető, ezzel lényegesen csökkentve a második csoport elemszámát 18 rekordra. A FIMIX-módszer segítségével két szegmens esetén a teljes minta $81,8 \%$ és 18,2\% arányban került elosztásra, míg három szegmens esetén $61,3 \%, 25,6 \%$ és 13,1\% volt a jellemző arány. Az eredmények két szegmenst feltételezve az első (nagyobb elemszámú) minta esetében nem történt jelentős változás, míg a második (kisebb elemszámú) minta esetében a $P E$-változó (performance expectancy - várható teljesítmény) hatása lényegesen csökkent $\beta=0,396$-ra, ezzel szemben a HB-változó (health belief - egészségtudat) hatása $\beta=0,523$-ra nőtt. Emellett megjelent az EE-változó (effort expectancy - várható erőfeszítés) negatív hatása $\beta=-0,201$ koefficiens mellett, míg a HM-változóra (hedonic motivation - hedonikus motiváció) szintén negatív hatás jellemző $\beta=-0,197$ mellett. Továbbá megjelent a PRI-változó (privacy-adatvédelem) hatása a BI-változóra $\beta=0,258$ koefficiens, illetve a PIN-változó (personal innovativeness - személyes innováció) hatása $\beta=0,176$ koefficiens mellett. Sajnos a minta a szegmentáltsága révén nem alkalmas bootstrap mintavételre, így további adatgyűjtést igényel a szignifikanciaszint ellenőrzése.

\section{A demográfia, az életmód és a vélemény közötti kapcsolat meghatározása}

A továbbiakban meghatározásra kerül az egyes demográfiai és életmódot reprezentáló adatok (intervallum, ordinális vagy nominális skála), illetve az egyes modellváltozók (ordinális skála) közötti kapcsolat, ordinális logisztikus regresszió segítségével (OLS), mivel az így megszerzett információk hasznosak lehetnek az esetleges csoportosítás vagy moderálás során az előbb bemutatott modell teljesítményének javítása érdekében. Független változóként több adat került kiválasztásra, beleértve egzakt 
változókat, mint a nem ( $D E 1)$, az életkor ( $D E 2)$, a jövedelem ( $D E 10)$, a napi számítógép használat $(S Z H)$, illetve számított mezőket az alábbi logika szerint kialakítva (7. táblázat).

\begin{tabular}{|c|c|c|c|}
\hline Kérdés & Jelenség & Változó & Leírás \\
\hline $\begin{array}{l}\text { Mi a foglalkozása? / Mi a végzett- } \\
\text { sége? }\end{array}$ & Végzettség & DE5 és DE7-7 & $\begin{array}{l}\text { A maximum középszintū } \\
\text { végzettséggel rendelke- } \\
\text { ző, illetve a felsőfokú } \\
\text { végzettséggel rendelkezők } \\
\text { vagy jelenleg felsőfokú } \\
\text { tanulmányaikat folytatók } \\
\text { halmazai. }\end{array}$ \\
\hline $\begin{array}{l}\text { Hány nap jellemző, hogy sportte- } \\
\text { vékenységet végezzen? / Ezek az } \\
\text { alkalmak rendszerint hány percig } \\
\text { tartanak? }\end{array}$ & Sporttevékenység & JE13 és JE14 & $\begin{array}{l}\text { A hetente jellemző spor- } \\
\text { tolások száma szorozva a } \\
\text { jellemző időtartammal. }\end{array}$ \\
\hline $\begin{array}{l}\text { Mi a véleménye az alábbi eszkö- } \\
\text { zökrőll? (pl.: okosóra, okosruházat, } \\
\text { okos asztali eszköz stb.) }\end{array}$ & Eszközhasználat & $A D G Y 1$ & $\begin{array}{l}\text { Amennyiben használ vagy } \\
\text { tervez használni egy felso- } \\
\text { rolt eszközt, egy ponttal nö } \\
\text { a változó értéke. }\end{array}$ \\
\hline $\begin{array}{l}\text { Mivel mérné az alábbi paraméte- } \\
\text { reket? (vérnyomás, véroxigénszint, } \\
\text { vércukorszint stb.) }\end{array}$ & $\begin{array}{l}\text { Eszközökre való nyi- } \\
\text { tottság }\end{array}$ & $A D G Y 16$ & $\begin{array}{l}\text { Amennyiben adott para- } \\
\text { méter méréséhez hordható } \\
\text { eszközt jelöl meg, egy pont- } \\
\text { tal nö a változó értéke. }\end{array}$ \\
\hline $\begin{array}{l}\text { Milyen célból osztaná meg adatait? } \\
\text { (orvosi leletek kiegészítése, egyén- } \\
\text { re szabott gyógyászat, edzéstervek } \\
\text { kialakítása stb.) }\end{array}$ & Adatvédelmi nyitottság 1. & $D A D E 4$ & $\begin{array}{l}\text { Minél több kijelölés történt, } \\
\text { annál nagyobb a változó } \\
\text { értéke. }\end{array}$ \\
\hline $\begin{array}{l}\text { Milyen adatokat osztana meg? } \\
\text { (vitális paraméterek, fitneszada- } \\
\text { tok, leletek) }\end{array}$ & Adatvédelmi nyitottság 2. & $A D E 5$ & $\begin{array}{l}\text { Minél több kijelölés történt, } \\
\text { annál nagyobb a változó } \\
\text { értéke. }\end{array}$ \\
\hline $\begin{array}{l}\text { Kivel osztaná meg a tárolt adato- } \\
\text { kat? (családtagok, orvos, munkál- } \\
\text { tató, állami intézmény stb.) }\end{array}$ & Adatvédelmi nyitottság 3. & $A D E 6$ & $\begin{array}{l}\text { Minél több kijelölés történt, } \\
\text { annál nagyobb a változó } \\
\text { értéke. }\end{array}$ \\
\hline
\end{tabular}

\section{7. táblázat: Kimeneti változókat befolyásoló tényezők (részlet)}

A számítások elvégzése során iteratív elven az említett változók és a modellváltozók között került meghatározásra az összefüggés. Ennek megfelelően az értelmezhetőség és a szignifikancia szint függvényében kerül elfogadásra vagy elvetésre a kapcsolat. Az eredmény bemutatása során azon variánsokra koncentrálunk, melyek mindkét feltételnek eleget tesznek, így hatásuk beilleszthető lenne a modellbe. Összességében 114 változó kombináció bizonyult szignifikánsnak a végkimenetel (látens változó paraméterei) befolyásolását illetően, 90\%-os megbízhatósággal számolva, melyből 31 változó közvetlenül a UTAUT-modell változóira volt befolyásoló hatással. A továbbiakban e változók kerülnek felsorolásra a standard hiba és a koefficiens figyelembevételével rendezve. A nem (DE1) kategóriaváltozón kívül minden prediktor skálaváltozóként került értelmezésre, mivel a közöttük lévő inkrementum egységesnek tekinthető. A számítások futtatásra kerültek minden mért változóra, hasonló eredményekkel (8. táblázat). 


\begin{tabular}{|c|c|c|c|c|}
\hline Kapcsolat & Koeff. & Std. hiba & t-érték & p-érték \\
\hline Eszközhasználat $\rightarrow$ BI1 & 0,513 & 0,082 & 6,250 & 0,000 \\
\hline Adatvédelmi nyitottság $1 . \rightarrow$ BI1 & 0,430 & 0,079 & 5,436 & 0,000 \\
\hline Eszközhasználat $\rightarrow$ PV1 & 0,422 & 0,079 & 5,368 & 0,000 \\
\hline Adatvédelmi nyitottság $1 . \rightarrow$ PE1 & 0,403 & 0,079 & 5,104 & 0,000 \\
\hline Adatvédelmi nyitottság $2 . \rightarrow$ BI1 & 0,672 & 0,134 & 5,022 & 0,000 \\
\hline Adatvédelmi nyitottság $2 . \rightarrow$ EE1 & 0,668 & 0,137 & 4,867 & 0,000 \\
\hline Eszközhasználat $\rightarrow$ SI1 & 0,355 & 0,076 & 4,648 & 0,000 \\
\hline Adatvédelmi nyitottság $1 . \rightarrow$ EE1 & 0,374 & 0,081 & 4,624 & 0,000 \\
\hline Eszközhasználat $\rightarrow$ PE1 & 0,359 & 0,078 & 4,580 & 0,000 \\
\hline Adatvédelmi nyitottság $3 . \rightarrow$ PE1 & 0,507 & 0,113 & 4,499 & 0,000 \\
\hline Adatvédelmi nyitottság $2 . \rightarrow$ PE1 & 0,600 & 0,134 & 4,491 & 0,000 \\
\hline Eszközhasználat $\rightarrow$ EE1 & 0,359 & 0,081 & 4,450 & 0,000 \\
\hline Adatvédelmi nyitottság $1 . \rightarrow$ HM1 & 0,311 & 0,074 & 4,199 & 0,000 \\
\hline Adatvédelmi nyitottság 3. $\rightarrow$ EE1 & 0,461 & 0,116 & 3,987 & 0,000 \\
\hline Adatvédelmi nyitottság $1 . \rightarrow$ FC1 & 0,332 & 0,087 & 3,822 & 0,000 \\
\hline Eszközhasználat $\rightarrow$ HM1 & 0,284 & 0,076 & 3,732 & 0,000 \\
\hline Adatvédelmi nyitottság $2 . \rightarrow$ FC1 & 0,515 & 0,140 & 3,689 & 0,000 \\
\hline Adatvédelmi nyitottság 3. $\rightarrow$ BI1 & 0,396 & 0,108 & 3,674 & 0,000 \\
\hline Adatvédelmi nyitottság $2 . \rightarrow$ HM1 & 0,443 & 0,129 & 3,432 & 0,001 \\
\hline Adatvédelmi nyitottság 3. $\rightarrow$ HM1 & 0,355 & 0,109 & 3,257 & 0,001 \\
\hline Eszközhasználat $\rightarrow$ FC1 & 0,247 & 0,082 & 3,024 & 0,002 \\
\hline Adatvédelmi nyitottság $3 . \rightarrow$ FC1 & 0,336 & 0,119 & 2,814 & 0,005 \\
\hline Eszközökre való nyitottság $\rightarrow$ EE1 & 0,143 & 0,055 & 2,616 & 0,009 \\
\hline Eszközökre való nyitottság $\rightarrow$ PE1 & 0,135 & 0,054 & 2,481 & 0,013 \\
\hline Életkor $\rightarrow$ EE1 & $-0,029$ & 0,012 & $-2,392$ & 0,017 \\
\hline Eszközökre való nyitottság $\rightarrow$ HM1 & 0,120 & 0,053 & 2,245 & 0,025 \\
\hline Végzettség $\rightarrow$ FC1 & 0,430 & 0,197 & 2,176 & 0,030 \\
\hline Életkor $\rightarrow$ PV1 & $-0,025$ & 0,012 & $-2,068$ & 0,039 \\
\hline Eszközökre való nyitottság $\rightarrow$ BI1 & 0,108 & 0,053 & 2,044 & 0,041 \\
\hline Nem (DE1Férfi) $\rightarrow$ FC1 & $-0,494$ & 0,268 & $-1,844$ & 0,065 \\
\hline Számítógép használat $\rightarrow$ PE1 & 0,068 & 0,039 & 1,745 & 0,081 \\
\hline Sporttevékenység $\rightarrow$ SI1 & 0,021 & 0,012 & 1,697 & 0,090 \\
\hline
\end{tabular}

8. táblázat: A modellen kívüli változók hatása az eredményre (részlet) 
Az ordinális logisztikus regresszió koefficiensének értelmezése az adatok természetétől függően eltérő. Skálatípusú adatok esetén meghatározásra kerül, hogy a független változó egységnyi változása (növekedése) esetén mennyiben változik annak esélye, hogy a függő változó más (magasabb) csoportba kerül. A felvázolt eredmények esetében csak a nem (DE1) tekinthető nominális változónak. Nominális változó esetén a koefficiens a csoportok közötti különbséget határozza meg az előbb említett módszerhez hasonlóan, ám a változás nem az inkrementumok mentén, hanem a csoportok között történik. Jelen példa alapján a férfiak magasabb értékelési kategóriába való tartozásához kapcsolódó esélyhányados logaritmusa -0,449 értékkel változik, így kisebb eséllyel $(O R=0,638)$ kerülnek magasabb csoportba a nőknél. Amennyiben a $B I$-változót vesszük figyelembe, láthatjuk, hogy minél több célból osztaná meg a résztvevő az adatait, annál nagyobb eséllyel választ magasabb használati hajlandóságot reprezentáló értékeket a válaszadás során. Ugyanez igaz a megosztott adatok csoportjára és a fogadó fél választását érintően is, mely alapján összességében az adatvédelem és az ezt érintő nyitottság hatással van a $B I$-változó alakulására. A jelenleg alkalmazott eszközök számára és a hordható eszközök felé mutatott nyitottságra vonatkozóan az egyes eszközök beszerzése ösztönözheti az új eszközök beszerzésére irányuló hajlandóságot. A BI1-változót érintő választások esélyeinek vizualizálása az alábbi, 18. ábra segítségével látható, mely kifejezi, hogy adott értékkel jellemzett független változó mellett milyen eséllyel értékeli a résztvevő a függő változót a jelölt szinten.
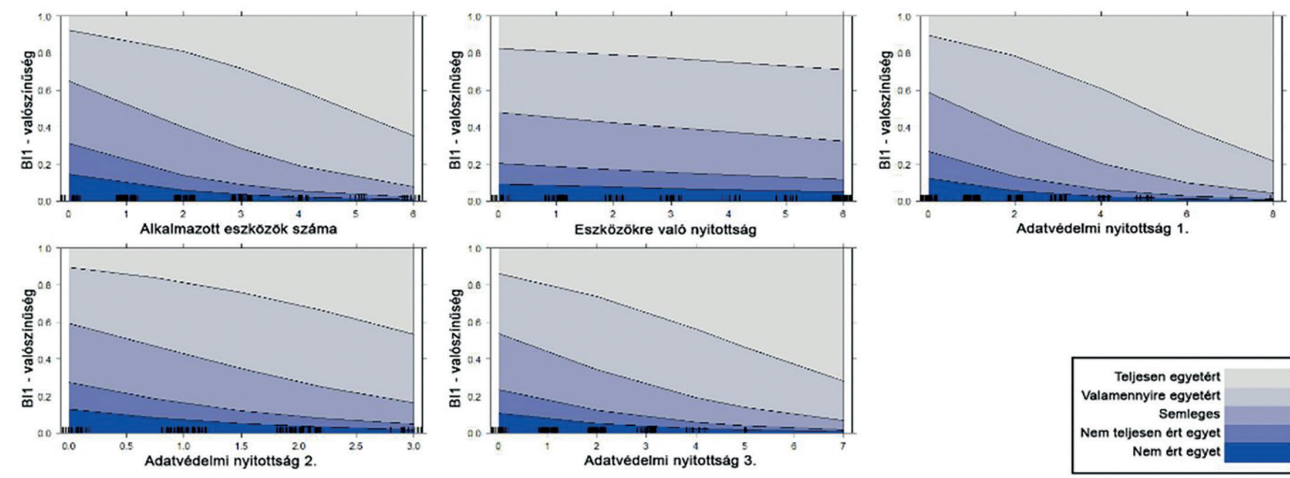

Adatvédelmi nyitottság 1.

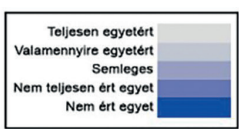

18. ábra: A BI változót befolyásoló tényezők az értékelés esélyhányadosaként kifejezve (saját ábra)

Ez alapján kifejezésre kerül, hogy mennyiben járul hozzá az adatvédelem kérdés - vagy épp az ebből érzékelt veszély értékelése - az eszközök használatának hajlandóságához. További változók kapcsán az életkor növekedésével csökken a magasabb kategóriába eső EE-változók (effort expectancy - várható erőfeszités) esélye, mely szintén érthető, de nem kimutatott hatás, emellett csökken a $P V$-változó (price value - ár érték) magasabb kategóriával jellemző értékelésének aránya, mely árérzékenység növekedésére utalhat. Ezzel ellenben a végzettség növekedésével növekszik az FC-változók (faciliating conditions - támogató feltételek) magasabb kategóriába érté- 
kelésének esélye. A magasabb számítógép használat (napi átlagos alkalom szorozva az átlagos időtartammal) növeli a PE (performance expectancy - várható teljesítmény) pozitív értékelésének esélyét, mely magyarázható az informatikai eszközökkel gyakran intearkcióba kerülő résztvevők magasabb igényével. Az említetteknek megfelelően a jövőben mindenképp érdemes a modellbe adatvédelmi szinteket reprezentáló látens változók beépítése. Jelen kutatás során három releváns változó került mérésre, kifejezve az általános véleményt, jellemző kockázatokat és jellemző veszélyeket, ám a modellalkotás során említett problémák miatt sajnos ezek beépítésére nem volt lehetőség.

A további eredményeket áttekintve láthatjuk, hogy gyakorlatilag az összes UTAUT2-modellben szereplő változóra vannak hatással bíró kiegészítő tényezők, ám a hatás erősség és jelenléte eltérő, ennek megfelelően további mérlegelésére van szükség a fontosságuk értékelése érdekében. A továbbiakban nem fogunk minden változót megtekinteni, mivel az arra jellemző tényezők kifejtésre kerültek a korábban bemutatott, 8 . táblázat segítségével.

Ezt követően neurális hálózat is alkalmazásra került kísérleti jelleggel a jövőbeli kutatás alátámasztása érdekében a BI-változó (behavior intention - viselkedési szándék) becslésére különböző változók figyelembevételével. A mesterséges intelligenciát rendszerint szenzoros mérések esetén tekintem relevánsnak, ahol az elemszám lehetővé teszi a megfelelő illeszkedés megvalósítását, ám az összehasonlítás érdekében érdemesnek láttam a jelen kontextusban történő alkalmazás tesztelését, mivel egyre gyakrabban találkozni a szakirodalomban hasonló megoldásokkal (Cheng, Wang és Pollastri 2008). Az első probléma, hogy a modellt alkotó kérdések ordinálisan kerülnek kifejezésre, ám találhatunk több releváns változót skála, illetve nominális formában is. Ennek megfelelően a modell kialakítása során figyelembe kellett venni e tényezőket, hiszen a legtöbb releváns algoritmus más adatstruktúrát vár el bemenetként és kimenetként egyaránt. A kódolás módosítását követően lehetőség van bináris osztályozásként kezelni a problémát, ahol a végső rétegen alkalmazott szigmoid aktivációs függvény révén az értékek 1 és 0 felé tendálnak, ám kategorikus keresztentrópia hibafüggvény számítása esetén nem kerül differenciálásra a sorrendiség. Ennek kiküszöbölése érdekében vagy egyedi hibafüggvény készítésére vagy megfelelő elemszámra van szükség. A hálózat kialakítása során egyszerủbb struktúra került kialakításra, a UTAT2-változók, emellett az ordinális logisztikus regresszió során alkalmazott változók kerültek alkalmazásra. A hálózat kialakítása során a változók csoportonként kerültek kezelésre, így a UTAUT2 különböző változói mind egy-egy külön rétegen kerültek be a hálózatba, ezt követően két rétegen keresztül kerültek feldolgozásra. Az ordinális regresszió számítása során alkalmazott változók egy külön rétegen keresztül jutottak a hálózatba, majd hasonlóképpen két rétegen keresztül kerültek feldolgozásra. A minden bementet követő két réteget követően azok összegzésre kerültek nyolc ponton, mely ezt követően a BI (behavior intention - viselkedési szándék) konstruktor által mért változókat reprezentálta. Az előzetes tapasztalatok alapján a hálózat képes volt felismerni a jellemző mintázatot, ám az alacsony elemszámra való tekintettel (a tanításra használat adatok aránya $80 \%$ volt) a módszer csak megközelítő előrejelzésre volt alkalmas. Ennek ellenére a kérdőív elemszámának esetleges bővítése esetén mindenképp érdemes megoldásnak bizonyul a módszer alkalmazása. 


\section{Összefoglalás}

A kutatás során az elsődleges cél volt az IoT-koncepció alapján kialakított, modern adatgyüjtő rendszerek (hordható, asztali és környezeti eszközök), illetve ehhez kapcsolódó, Big Data koncepció alapján kialakított elemző rendszerek (szolgáltatások) kapcsán felmerülő fogyasztói tapasztalatok, igények felmérésé, illetve a diffúziójukat (használati hajlandóságot) befolyásoló faktorok vizsgálata. Az első lépés egy kvantitatív szakirodalmi elemzés megvalósítása volt, ezzel meghatározva a területre jellemző fő témaköröket, a közöttük jellemző kapcsolatokat, illetve ezek időbeli változását. A kutatás folytatásaként egy ötlépcsős kérdőív került kialakításra, melynek modellváltozói a UTAUT2-technológia elfogadottság modelljére épületek, kiegészítve azt összesen 31 látens változó kapcsolatának vizsgálata érdekében. Az elemzés során a leíró adatok mellett strukturális egyenletek modellezése került alkalmazásra (PLS-SEM). A modellhez alkalmazott adathalmaz, mely $n=229$ rekordból áll, megfelelt a reflektív modellektől elvárt kritériumnak, beleértve a belső konzisztencia, konvergens és diszkrimináns érvényességet. Eredményként megállapításra került, hogy az alkalmazott UTAUT2-változók közül szignifikánsan, az adott mintára vonatkozóan a $P E$-változó (performance expectancy - várható teljesítmény) változó, emellett az ezt meghatározó $R B$ - (reliability - megbízhatóság) és AES-változó (aesthetics - esztétika) befolyásolta leginkább a viselkedési hajlandóságot. Az eredmény mondhatni nem egyedi, mivel több hasonló konklúzióval találkozhatunk, ám az adathalmaz áttekintése során felmerült a nem megfigyelt heterogenitás lehetősége, melynek lehetséges megoldására érdekében több módszer került alkalmazására, beleértve a FIMIX-módszert a megfelelő szegmentálás, illetve ordinális logisztikus regresszió a moderátorváltozók meghatározása érdekében. Ennek alapján kimutatásra került a nem megfigyelt heterogenitás vélhető jelenléte, melynek megoldásához sikerült alkalmazni egyes módszereket, ám az elemszám nem tette lehetővé a megfelelő szegmentálást. A lehetőségek áttekintését követően az adathalmaz tesztelésre került neurális hálózat segítségével a nemlineáris kapcsolatok és mintázatok feltérképezésére, mely a tapasztalatok alapján megfelelő elemszám esetén hatékony alternatívaként szolgálhat a további kutatás során.

A kérdőív elemzésekor számos limitáció került meghatározásra, mely mindenképp figyelmet érdemel a jövőben. Az első probléma, hogy az elemszám nem teszi lehetővé az alcsoportok megfelelő szegmentálását a szignifikancia szint megőrzése mellett. További probléma a megfelelő adattisztító algoritmus kialakítása a rekordok tartalmi helyességének biztosítása érdekében, illetve a megfelelő moderátorok feltérképezése. Az eddigi tapasztalatok alapján az adatvédelemmel kapcsolatos faktorok, illetve a korábbi tapasztalat szerepet tölthetnek be az elfogadottság kérdésében, így kiegészítésként érdemes lehet a terület ezen aspektusának feltérképezése a modell módosítása érdekében. Jelen kutatás folytatásaként érdemes lehet a szegmentálás eredményként létrehozott csoportok közötti különbség meghatározása klaszteranalízis segítségével az életmód egyes változóit (BMI, ülő tevékenység, fizikai munka, sporttevékenység stb.), illetve digitális tapasztalat (számítógép használat, mobiltelefon használat átlagos időtartamot és diverzitást tekintve) paramétereit figyelembe véve. Az említett adatok mérésre kerültek, így az említett koncepció megvalósításra kerülhetne a meglévő adathalmaz használatával. 


\section{Irodalom}

Akter, Sharmin, Imran Mahmud, Fahad Bin Zamal és Jannatul Ferdush. „An investigation on factors influencing smart watch adoption: A partial least squares approach.” In International Conference on Cyber Security and Computer Science Proceeding Book, 138-141. Turkey: International Conference on Cyber Security and Computer Science, 2018. https://iconcs.org/iconcs2018/home files/ICONCS Proceedingx.pdf

Alemdar, Hande és Cem Ersoy. „Wireless sensor networks for healthcare: A survey.” Computer Networks 54, no. 15 (2010): 2688-2710. https://doi.org/10.1016/j.comnet.2010.05.003.

Aria, Massimo és Corrado Cuccurullo. „bibliometrix: An R-tool for comprehensive science mapping analysis.” Journal of Informetrics 11, no. 4 (2017): 959-75.

https://doi.org/10.1016/j.joi.2017.08.007.

Ariza-Monte, Antonio, Antonio L. Leal-Rodríguez, Jesús Ramírez-Sobrino és Horacio MolinaSánchez. „Safeguarding health at theworkplace: A study of work engagement, authenticity and subjective wellbeing among religious workers." International Journal of Environmental Research and Public Health 16, no. 17 (2019): 1-18. https://doi.org/10.3390/ijerph16173016.

Balapour, Ali, Iris Reychav, Rajiv Sabherwal és Joseph Azuri. „Mobile technology identity and self-efficacy: Implications for the adoption of clinically supported mobile health apps.” International Journal of Information Management 49, no. March (2019): 58-68.

https://doi.org/10.1016/j.ijinfomgt.2019.03.005.

Baudier, Patricia, Chantal Ammi és Matthieu Deboeuf-Rouchon. „Smart home: Highly-educated students’ acceptance.” Technological Forecasting and Social Change 153, no. April (2018): 1-19. https://doi.org/10.1016/j.techfore.2018.06.043.

Becker, Dennis. „Acceptance of Mobile Mental Health Treatment Applications.” In Procedia Computer Science 98, 220-227. Germany: The 6th International Conference on Current and Future Trends of Information and Communication Technologies in Healthcare (ICTH), 2016. https://doi.org/10.1016/j.procs.2016.09.036.

Bosona, Techane és Girma Gebresenbet. „Food traceability as an integral part of logistics management in food and agricultural supply chain.” Food Control 33, no. 1 (2013): 32-48. https://doi.org/10.1016/j.foodcont.2013.02.004.

Cassel, Claes, Peter Hackl és Anders H. Westlund. „Robustness of partial least-squares method for estimating latent variable quality structures.” Journal of Applied Statistics 26, no. 4 (1999): 435-46. https://doi.org/10.1080/02664769922322.

Chan, Marie, Daniel Estève, Jean Yves Fourniols, Christophe Escriba és Eric Campo. „Smart wearable systems: Current status and future challenges.” Artificial Intelligence in Medicine 56, no. 3 (2012): 137-156. https://doi.org/10.1016/j.artmed.2012.09.003.

Chang, Shou-Chi és Liang-Chuan Wu. „Exploring Consumers' Intention to Accept the Smartwatch.” In Asian Conference on Psychology and Behavioral Sciences 2015 Official Conference Proceedings, 421-428. Japan: The Asian Conference on Psychology and Behavioral Sciences, 2015. http://papers.iafor.org/wp-content/uploads/conferenceproceedings/ACP/ACP2015_proceedings.pdf

Cheng, Jianlin, Zheng Wang és Gianluca Pollastri. „A neural network approach to ordinal regression.” In Proceedings of the International Joint Conference on Neural Networks, 12791284. Hong Kong: IEEE World Congress on Computational Intelligence, 2008. https://doi.org/10.1109/IJCNN.2008.4633963. 
Cheung, Man Lai, Ka Yin Chau, Michael Huen Sum Lam, Gary Tse, Ka Yan Ho, Stuart W. Flint, David R. Broom, Ejoe Kar Ho Tso és Ka Yiu Lee. „Examining Consumers’ Adoption of Wearable Healthcare Technology: The Role of Health Attributes.” International journal of environmental research and public health 16, no. 13 (2019): 1-16.

https://doi.org/10.3390/ijerph16132257.

Cho, Insu and Heejun Park. „The influential factors on the diffusion of smartwatches in Korea.” International Journal of Technology Management 72, no. 1/2/3 (2016): 230.

https://doi.org/10.1504/IJTM.2016.080537.

Choi, Jaewon and Seongcheol Kim. „Is the smartwatch an IT product or a fashion product? A study on factors affecting the intention to use smartwatches." Computers in Human Behavior 63, October (2016): 777-786. https://doi.org/10.1016/j.chb.2016.06.007.

Churchill Jr, Gilbert A. „Paradigm for developing better measures of marketing constructs.” Journal of Marketing Research 16, no. 1 (1979): 64-73. https://www.jstor.org/stable/3150876.

Conroy, Ronán. „Sample size A rough guide.” 2015, 1-30. https://pdfs.semanticscholar.org/4781/878153e13322c028c7d8970e7f52fbaa102a.pdf.

Dawar, Niraj és Philip Parker. „Marketing Universals: Consumers’ Use of Brand Name, Price, Physical Appearance and Retailer Reputation as Signals of Product Quality” Journal of Marketing 58, no. 2 (1994): 81.

https://doi.org/10.2307/1252271.

Demski, Hans, Sebastian Garde és Claudia Hildebrand. „Open data models for smart health interconnected applications: The example of openEHR Standards, technology, machine learning and modeling.” BMC Medical Informatics and Decision Making 16, no. 1 (2016): 1-9. https://doi.org/10.1186/s12911-016-0376-2.

Dijkstra, Theo K. és Jörg Henseler. „Consistent and asymptotically normal PLS estimators for linear structural equations.” Computational Statistics and Data Analysis 81, no. July (2015): 10-23. https://doi.org/10.1016/j.csda.2014.07.008.

Din, Sadia és Anand Paul. „Smart health monitoring and management system: Toward autonomous wearable sensing for Internet of Things using big data analytics." Future Generation Computer Systems 91, no. February (2019): 611-619.

https://doi.org/10.1016/j.future.2017.12.059.

Duarte, Paulo és José Carlos Pinho. „A mixed methods UTAUT2-based approach to assess mobile health adoption.” Journal of Business Research 102, no. May (2019): 140-50.

https://doi.org/10.1016/j.jbusres.2019.05.022.

Dutot, Vincent, Veera Bhatiasevi és Nadim Bellallahom. „Applying the technology acceptance model in a three-countries study of smartwatch adoption.” Journal of High Technology Management Research 30, no. 1 (2019): 1-14.

https://doi.org/10.1016/j.hitech.2019.02.001.

Dutta, Bireswar, Mei Hui Peng és Shu Lung Sun. „Modeling the adoption of personal health record (PHR) among individual: the effect of health-care technology self-efficacy and gender concern.” Libyan Journal of Medicine 13, no. 1 (2018): 1-12. https://doi.org/10.1080/19932820.2018.1500349.

Farahani, Bahar, Farshad Firouzi, Victor Chang, Mustafa Badaroglu, Nicholas Constant és Kunal Mankodiya. „Towards fog-driven IoT eHealth: Promises and challenges of IoT in medicine and healthcare.” Future Generation Computer Systems 78, no. January (2018): 659-676. https://doi.org/10.1016/j.future.2017.04.036. 
Faul, Franz, Edgar Erdfelder, Albert-Georg Lang és Axel Buchner. „G*Power 3: A flexible statistical power analysis program for the social, behavioral and biomedical sciences." Behavior Research Methods 39, no. 2 (2007): 175-191. https://doi.org/10.3758/BF03193146.

Gao, Yiwen, He Li és Yan Luo. „An empirical study of wearable technology acceptance in healthcare.” Industrial Management and Data Systems 115, no. 9 (2015): 1704-1723. https://doi.org/10.1108/IMDS-03-2015-0087.

Gómez, Jorge, Byron Oviedo és Emilio Zhuma. „Patient Monitoring System Based on Internet of Things.” Procedia Computer Science 83, no. Ant (2016): 90-97.

https://doi.org/10.1016/j.procs.2016.04.103.

$\mathrm{Gu}$, Zhongwei, June Wei és Fuyuan Xu. „An empirical study on factors influencing consumers’ initial trust in wearable commerce.” Journal of Computer Information Systems 56, no. 1 (2015): 79-85. https://doi.org/10.1080/08874417.2015.11645804.

Hahn, Carsten, Michael D Johnson andreas Herrmann és Frank Huber. „Capturing Customer Heterogeneity using a Finite Mixture PLS Approach.” Schmalenbach Business Review 54, no. 3 (2002): 243-269. https://doi.org/10.1007/BF03396655.

Hair, Joseph F., G. Thomas. M. Hult, Christian M. Ringle és Marko Sarsedt. A Primer on Partial Least Squares Structural Equation Modeling (PLS-SEM). United States: SAGE Publications, 2016.

https://us.sagepub.com/en-us/nam/a-primer-on-partial-least-squares-structural-equationmodeling-pls-sem/book244583

Hair, Joseph F, Jeffrey Joe Risher, Marko Sarstedt és Christian M Ringle. „When to use and how to report the results of PLS-SEM.” European Business Review 31, no. 1 (2019): 2-24. https://doi.org/10.1108/EBR-11-2018-0203.

Handayani, Putu Wuri, Ibad Rahadian Saladdin, Ave Adriana Pinem, Fatimah Azzahro, Achmad Nizar Hidayanto és Dumilah Ayuningtyas. „Health referral system user acceptance model in Indonesia.” Heliyon 4, no. 12 (2018): 1-33. https://doi.org/10.1016/j.heliyon.2018.e01048.

Holden, Richard J. és Ben-Tzion Tzion Karsh. „The Technology Acceptance Model: Its past and its future in health care.” Journal of Biomedical Informatics 43, no. 1 (2010): 159-172. https://doi.org/10.1016/j.jbi.2009.07.002.

Hoque, Rakibul és Golam Sorwar. „Understanding factors influencing the adoption of mHealth by the elderly: An extension of the UTAUT model." International Journal of Medical Informatics 101, no. September (2017): 75-84. https://doi.org/10.1016/j.ijmedinf.2017.02.002.

Hsiao, Kuo Lun és Chia Chen Chen. „What drives smartwatch purchase intention? Perspectives from hardware, software, design and value.” Telematics and Informatics 35, no. 1 (2018): 103-113. https://doi.org/10.1016/j.tele.2017.10.002.

Hung, Wei Chih, Fan Shen, Yi Leh Wu, Maw Kae Hor és Cheng Yuan Tang. „Activity Recognition with sensors on mobile devices." Proceedings - International Conference on Machine Learning and Cybernetics 2, (2014): 449-454. https://doi.org/10.1109/ICMLC.2014.7009650.

Indrakumari, R., T. Poongodi, P. Suresh és B. Balamurugan. The growing role of Internet of Things in healthcare wearables. In Emergence of Pharmaceutical Industry Growth with Industrial IoT Approach, 163-194. Netherlands: Elsevier (2020).

https://doi.org/10.1016/b978-0-12-819593-2.00006-6.

Jeong, Seok Chan, Sang Hyun Kim, Ji Yeon Park és Beomjin Choi. „Domain-specific innovativeness and new product adoption: A case of wearable devices.” Telematics and Informatics 34, no. 5 (2017): 399-412. https://doi.org/10.1016/j.tele.2016.09.001. 
Kamada, Tomihisa és Satoru Kawai. „An algorithm for drawing general undirected graphs.” Information Processing Letters 31, no. 1 (1989): 7-15.

https://doi.org/10.1016/0020-0190(89)90102-6.

Kao, Yu-Sheng, Kazumitsu Nawata és Chi-Yo Huang. „An Exploration and Confirmation of the Factors Influencing Adoption of IoT-Based Wearable Fitness Trackers.” International Journal of Environmental Research and Public Health 16, no. 18 (2019): 1-31. https://doi.org/10.3390/ijerph16183227.

Khalil, Nacer, Mohamed Riduan Abid, Driss Benhaddou és Michael Gerndt. „Wireless sensors networks for Internet of Things.” In 2014 IEEE Ninth International Conference on Intelligent Sensors, Sensor Networks and Information Processing Conference Proceedings, 21-24. Singapore: IEEE Ninth International Conference on Intelligent Sensors, Sensor Networks and Information Processing, 2014. https://doi.org/10.1109/ISSNIP.2014.6827681.

Kijsanayotin, Boonchai, Supasit Pannarunothai és Stuart M. Speedie. „Factors influencing health information technology adoption in Thailand's community health centers: Applying the UTAUT model.” International Journal of Medical Informatics 78, no. 6 (2009): 404-416. https://doi.org/10.1016/j.ijmedinf.2008.12.005.

Kumar, P. Kishore. „Consumer Perception and Purchase Intention towards Smartwatches.” IOSR Journal of Business and Management 19, no. 01 (2017): 26-28. https://doi.org/10.9790/487X-1901042628.

Kwon, Ohbyung, Jae Moon Shim és Geunchan Lim. „Single activity sensor-based ensemble analysis for health monitoring of solitary elderly people." Expert Systems with Applications 39, no. 5 (2012): 5774-5783. https://doi.org/10.1016/j.eswa.2011.11.090.

Li, Junde, Qi Ma, Alan HS. Chan és S.S. S. Man. „Health monitoring through wearable technologies for older adults: Smart wearables acceptance model.” Applied Ergonomics 75, no. October (2019): 162-169. https://doi.org/10.1016/j.apergo.2018.10.006.

Marakhimov, Azizbek és Jaehun Joo. „Consumer adaptation and infusion of wearable devices for healthcare.” Computers in Human Behavior 76, no. November (2017): 135-148. https://doi.org/10.1016/j.chb.2017.07.016.

McConnell, Michael V., Mintu P. Turakhia, Robert A. Harrington, Abby C. King és Euan A. Ashley. „Mobile Health Advances in Physical Activity, Fitness and Atrial Fibrillation.” Journal of the American College of Cardiology 71, no. 23 (2018): 2691-2701. https://doi.org/10.1016/j.jacc.2018.04.030.

Merilampi, Sari és Andrew Sirkka. Introduction to Smart eHealth and eCare Technologies. United States: CRC Press, 2016.

Nascimento, Bruno, Tiago Oliveira és Carlos Tam. „Wearable technology: What explains continuance intention in smartwatches?” Journal of Retailing and Consumer Services 43, no. April (2018): 157-169. https://doi.org/10.1016/j.jretconser.2018.03.017.

Ni, Jui Chung, Chu Sing Yang, Jiun Kai Huang és Liang Cheng Shiu. „Combining Non-Invasive Wearable Device and Intelligent Terminal in HealthCare IoT.” In Procedia Computer Science 154: 161-166. India: 8th International Congress of Information and Communication Technology (ICICT-2019), 2019.

https://doi.org/10.1016/j.procs.2019.06.024.

O’Brien, Robert M. „A caution regarding rules of thumb for variance inflation factors.” Quality and Quantity 41, no. 5 (2007): 673-690. https://doi.org/10.1007/s11135-006-9018-6. 
Oom do Valle, Patrícia és Guy Assaker. „Using Partial Least Squares Structural Equation Modeling in Tourism Research: A Review of Past Research and Recommendations for Future Applications.” Journal of Travel Research 55, no. 6 (2016): 695-708. https://doi.org/10.1177/0047287515569779.

Padikkapparambil, Jinesh, Cornelius Ncube, Krishna Kant Singh és Akansha Singh. „Internet of Things technologies for elderly health-care applications.” In Emergence of Pharmaceutical Industry Growth with Industrial IoT Approach, 217-243. Netherlands: Elsevier (2020). https://doi.org/10.1016/b978-0-12-819593-2.00008-x.

Panesar, Arjun. Machine Learning and AI for Healthcare. United States: Apress, 2019. https://doi.org/10.1007/978-1-4842-3799-1.

Papa, Armando, Monika Mital, Paola Pisano és Manlio Del Giudice. „E-health and wellbeing monitoring using smart healthcare devices: An empirical investigation.” Technological Forecasting and Social Change 153, no. February (2018): 119226. https://doi.org/10.1016/j.techfore.2018.02.018.

Paulin, Alois. „Data Traffic Forecast in Health 4.0”. In Health 4.0: How Virtualization and Big Data are Revolutionizing Healthcare, 39-60. Cham: Springer International Publishing (2017). https://doi.org/10.1007/978-3-319-47617-9_3.

Pham, Minh, Yehenew Mengistu, Ha Do és Weihua Sheng. „Delivering home healthcare through a Cloud-based Smart Home Environment (CoSHE).” Future Generation Computer Systems 81, no. April (2018): 129-140. https://doi.org/10.1016/j.future.2017.10.040.

Puri, Vikram, Raghvendra Kumar, Dac Nhuong Le, Sandeep Singh Jagdev és Nidhi Sachdeva. „BioSenHealth 2.0-a low-cost, energy-efficient Internet of Things-based blood glucose monitoring system.” In Emergence of Pharmaceutical Industry Growth with Industrial IoT Approach, 305-324. Netherlands: Elsevier, 2020.

https://doi.org/10.1016/b978-0-12-819593-2.00011-x.

Rajanen, Dorina és Min Weng. „Digitization for fun or reward? A study of acceptance of wearable devices for personal healthcare." In Proceedings of the 21st International Academic Mindtrek Conference, 154-163. United States: 21st International Academic Mindtrek Conference, 2017. https://doi.org/10.1145/3131085.3131118.

Resende Silva, Bruno Vieira és Juan Cui. „A Survey on Automated Food Monitoring and Dietary Management Systems.” Journal of Health \& Medical Informatics 08, no. 03 (2017): 1-7. https://doi.org/10.4172/2157-7420.1000272.

Rondan-Cataluña, Francisco Javier, Jorge Arenas-Gaitán és Patricio Esteban Ramírez-Correa. „A comparison of the different versions of popular technology acceptance models a nonlinear perspective.” Kybernetes 44, no. 5 (2015): 788-805.

https://doi.org/10.1108/K-09-2014-0184.

Rupp, Michael A., Jessica R. Michaelis, Daniel S. McConnell és Janan A. Smither. „The role of individual differences on perceptions of wearable fitness device trust, usability and motivational impact.” Applied Ergonomics 70, no. April (2018): 77-87. https://doi.org/10.1016/j.apergo.2018.02.005.

Salinas Segura, Alexander és Frédéric Thiesse. „Extending Utaut2 To Explore Pervasive.” In ECIS 2015 Proceedings: 1-17. Germany: Twenty-Third European Conference on Information Systems (ECIS), 2015. https://doi.org/10.18151/7217456.

Schumacker, Randall E., Lomax, Richard G. A Beginner's Guide to Structural Equation Modeling. New York: Routledge, 2015. https://doi.org/10.4324/9781315749105. 
Selya, Arielle S. és Drake Anshutz. Machine learning for the classification of obesity from dietary and physical activity patterns. Smart Innovation, Systems and Technologies. Germany: Springer International Publishing, 2018. https://doi.org/10.1007/978-3-319-77911-9_5.

Sikorska-Siudek, Katarzyna, Małgorzata Olędzka-Oręziak és Beata Parzuchowska. „Health benefits of physical activity: the evidence.” CMAJ 174, no. 6 (2006): 801-809.

https://doi.org/10.1503/cmaj.051351

Squillacciotti, Silvia. „Prediction Oriented Classification in PLS Path Modeling.” In Handbook of Partial Least Squares, 219-233. Berlin, Heidelberg: Springer Berlin Heidelberg, 2010. https://doi.org/10.1007/978-3-540-32827-8_10.

Statista. „Number of Internet of Things (IoT) active connections in healthcare in the European Union (EU) in 2016, 2019, 2022 and 2025.” (2020).

https://www.statista.com/statistics/691848/iot-active-connections-in-healthcare-in-the-eu/.

Su, Xing, Hanghang Tong és Ping Ji. „Activity recognition with smartphone sensors.” Tsinghua Science and Technology 19, no. 3 (2014): 235-249. https://doi.org/10.1109/TST.2014.6838194.

Sung, Wen Tsai és Sung Jung Hsiao. „The application of thermal comfort control based on Smart House System of IoT." Measurement:Journal of the International Measurement Confederation 149, no. January (2020): 106997. https://doi.org/10.1016/j.measurement.2019.106997.

Suzuki, Takuji, Hirokazu Tanaka, Shigenobu Minami, Hiroshi Yamada és Takashi Miyata. „Wearable wireless vital monitoring technology for smart health care.” In International Symposium on Medical Information and Communication Technology, ISMICT (2013), 1-4. Japan: 7th International Symposium on Medical Information and Communication Technology (ISMICT). https://doi.org/10.1109/ISMICT.2013.6521687.

Talukder, Md Shamim, Raymond Chiong, Yukun Bao és Babur Hayat Malik. „Acceptance and use predictors of fitness wearable technology and intention to recommend: An empirical study.” Industrial Management and Data Systems 119, no. 1 (2019): 170-88. https://doi.org/10.1108/IMDS-01-2018-0009.

Tavares, Jorge és Tiago Oliveira. „New integrated model approach to understand the factors that drive electronic health record portal adoption: Cross-sectional national survey.” Journal of Medical Internet Research 20, no. 11 (2018): 1-17. https://doi.org/10.2196/11032.

Thompson, Ronald L., Christopher A. Higgins and Jane M. Howell. „Influence of experience on personal computer utilization: Testing a conceptual model.” Journal of Management Information Systems 11, no. 1 (1994): 167-187.

https://doi.org/10.1080/07421222.1994.11518035.

Thuemmler, Christoph. „The Case for Health 4.0.” In Health 4.0: How Virtualization and Big Data are Revolutionizing Healthcare, 1-22. Cham: Springer International Publishing, 2017. https://doi.org/10.1007/978-3-319-47617-9_1.

Uddin, Md.Ashraf andrew Stranieri, Iqbal Gondal és Venki Balasubramanian. „Blockchain Leveraged Decentralized IoT eHealth Framework.” Internet of Things 9, no. March (2020), 100159. https://doi.org/10.1016/j.iot.2020.100159.

Ullah, Farhan, Muhammad Asif Habib, Muhammad Farhan, Shehzad Khalid, Mehr Yahya Durrani és Sohail Jabbar. „Semantic interoperability for big-data in heterogeneous IoT infrastructure for healthcare.” Sustainable Cities and Society 34, no. March (2017): 90-96. https://doi.org/10.1016/j.scs.2017.06.010.

Venkatesh, Morris, Davis és Davis. „User Acceptance of Information Technology: Toward a Unified View.” MIS Quarterly 27, no. 3 (2003): 425-478. https://doi.org/10.2307/30036540. 
Venkatesh, Viswanath, James Y L Thong és Xin Xu. „Consumer acceptance and use of information technology: Extending the unified theory of acceptance and use of technology.” MIS Quarterly 36, no. 1 (2012): 157-178. https://doi.org/10.2307/41410412.

Weinhard, Alexander, Matthias Hauser és Frédéric Thiesse. „Explaining Adoption of Pervasive Retail Systems with a Model based on UTAUT2 and the Extended Privacy Calculus.” In PACIS 2017 Proceedings, 1-14. Malaysia: Pacific Asia Conference on Information Systems, 2017. https://aisel.aisnet.org/pacis2017/217/

Weng, Min. „The acceptance of wearable devices for personal healthcare in China.” University of Oulu, 2016. http://jultika.oulu.fi/Record/nbnfioulu-201605111684.

WHO. „Diet, nutrition and the prevention of chronic diseases.” WHO Technical Report Series, 2003. https://www.fao.org/3/ac911e/ac911e00.htm.

Xing, Jiang és Yunru Zhu. „A survey on body area network.” In Proceedings 5th International Conference on Wireless Communications, Networking and Mobile Computing, 4-7. China: 5th International Conference on Wireless Communications, Networking and Mobile Computing, 2009. https://doi.org/10.1109/WICOM.2009.5302579.

Yang, Heetae, Jieun Yu, Hangjung Zo és Munkee Choi. „User acceptance of wearable devices: An extended perspective of perceived value.” Telematics and Informatics 33, no. 2 (2016): 256-269. https://doi.org/10.1016/j.tele.2015.08.007.

Yin, Xizhe, Weiming Shen, Jagath Samarabandu és Xianbin Wang. „Human activity detection based on multiple smart phone sensors and machine learning algorithms.” In Proceedings of the 2015 IEEE 19th International Conference on Computer Supported Cooperative Work in Design, 582-587. Italy: IEEE 19th International Conference on Computer Supported Cooperative Work in Design (CSCWD), 2015. https://doi.org/10.1109/CSCWD.2015.7231023.

YIN, Yuehong, Yan Zeng, Xing Chen and Yuanjie Fan. „The internet of things in healthcare: An overview.” Journal of Industrial Information Integration 1, no March (2016): 3-13. https://doi.org/10.1016/j.jii.2016.03.004.

Zahra, F., M.B. Alexandri, M. Purnomo, R. Arifianti, A. Muftiadi, T. Herawati, D. Nugroho és B. Ruslan. „User Behaviour Intention Using Utaut2 Model: a Systematic Literature Review.” Russian Journal of Agricultural and Socio-Economic Sciences 92, no. 8 (2019): 265-273. https://doi.org/10.18551/rjoas.2019-08.29.

Zhang, Min, Meifen Luo, Rui Nie és Yan Zhang. „Technical attributes, health attribute, consumer attributes and their roles in adoption intention of healthcare wearable technology.” International Journal of Medical Informatics 108, no. December (2017): 97-109. https://doi.org/10.1016/j.ijmedinf.2017.09.016.

Zhang, Yiyu, Chaoyuan Liu, Shuoming Luo, Yuting Xie, Fang Liu, Xia Li és Zhiguang Zhou. „Factors influencing patients' intention to use diabetes management apps based on an extended unified theory of acceptance and use of technology model: Web-based survey.” Journal of Medical Internet Research 21, no. 8 (2019): 1-17. https://doi.org/10.2196/15023.

Zualkernan, I., F. Aloul, S. Shapsough, A. Hesham és Y. El-Khorzaty. „Emotion recognition using mobile phones.” Computers and Electrical Engineering 60, no. May (2017): 1-13. https://doi.org/10.1016/j.compeleceng.2017.05.004. 